\title{
La evolución histórica del silencio administrativo: de los Estatutos de Calvo-Sotelo hasta la Ley 30/1992
}

\author{
Vicenç Aguado i Cudolà \\ Doctor en Derecho \\ Profesor titular interino de Derecho administrativo \\ Universidad de Barcelona
}

Sumario: I. PLANTEAMIENTO GENERAL. II. LOS ESTATUTOS MUNICIPAL Y PROVINCIAL DE CALVO SOTELO: HACIA UNA SUPERACIÓN DEL CARÁCTER FRAGMENTARIO DE LA NORMATIVA DEL SILENCIO. III. LA LEGISLACION Y LA JURISPRUDENCIA EN LA II REPÚBLICA: EL SURGIMIENTO DE LA CONCEPCIÓN GARANTISTA DEL SILENCIO Y LA IMPLANTACIÓN DEL MECANISMO DE LA DENUNCIA DE LA MORA. IV. EL SILENCIO ADMINISTRATIVO EN EL REGIMEN DEL GENERAL FRANCO: ¿UNA TÉCNICA AL SERVICIO DEL «ESTADO ADMINISTRATIVO DE DERECHO»? V. EL SILENCIO ADMINISTRATIVO EN LA TRANSICIÓN ESPAÑOLA Y LA INCORPORACIÓN A LA EUROPA COMUNITARIA: DE UN MECANISMO BÁSICAMENTE PROCESAL HACIA LAS NUEVAS TENDENCIAS DE SIMPLIFICACIÓN ADMINISTRATIVA. VI. RECAPITULACIÓN: LAS DIVERSAS CONCEPCIONES DEL SILENCIO ADMINISTRATIVO COMO RESULTADO DE LA EVOLUCIÓN HISTÓRICA DEL PROPIO ESTADO.

\section{PLANTEAMIENTO GENERAL}

El silencio administrativo surge al compás de la propia jurisdicción contencioso-administrativa ya desde sus mismos inicios, según hemos tenido oportunidad de demostrar en otro trabajo '. Ahora bien, ello se realiza con alcance limitado a ciertos ámbitos y procedimientos. No será, por tanto, hasta el presente siglo cuando se empezará a superar el carácter fragmentario y disperso de la normativa en dos momentos bien concretos: primero para la Administración local con los Estatutos de Calvo-Sotelo y posteriormente para todas las Administraciones con la Ley de 17 de julio de 1958, de procedimiento administrativo. Curiosamente, el contexto político existente en ambos períodos favorecerá la consolidación de la técnica del silencio administrativo como uno de los mecanismos de acceso a la jurisdicción contencioso-administrativa. Durante la breve experiencia republicana se introducirá el carácter garantizador

\footnotetext{
1 Vid. Vicenç AGUADO I CuDOLA, «Los orígenes del silencio administrativo en la formación del Estado de Derechos en RAP (en prensa).
} 
del silencio, concebido hasta entonces como una técnica al servicio de la Administración y del buen orden del procedimiento. Perspectiva garantizadora que será retomada durante el franquismo por la doctrina que ha construido nuestro moderno Derecho administrativo. Toda esta evolución, que examinaremos en las páginas siguientes, constituye sin lugar a dudas un importante referente que debemos tener en cuenta en el momento actual, ya sea desde una perspectiva de interpretación de la normativa actualmente vigente, ya sea desde un planteamiento de lege ferenda destinado a perfeccionar y mejorar tal regulación. En cualquier caso, a las irrenunciables garantías se une en la actualidad la necesidad de instrumentar una Administración diligente y eficaz, que cumpla en el tiempo adecuado las necesidades de sus ciudadanos.

\section{LOS ESTATUTOS MUNICIPAL Y PROVINCIAL DE CALVO SOTELO: HACIA UNA SUPERACIÓN DEL CARÁCTER FRAGMENTARIO DE LA NORMATIVA DEL SILENCIO}

La crisis del parlamentarismo liberal, cuyas deficiencias van arrastrándose desde principios de siglo, lleva al implantamiento de regímenes autocráticos y totalitarios en el período de entreguerras. Durante este período se produjeron una serie de acontecimientos decisivos que condicionaron la evolución posterior. En España debe destacarse la dictadura del General Primo de Rivera (1923-1930). Estamos, sin duda, ante un período importante para el Derecho administrativo por los hechos que se producen y por su trascendencia ${ }^{2}$, no obstante estas transformaciones no han sido objeto de la atención que merecían. La ausencia de Parlamento posibilita que se lleven a cabo, al menos sobre el papel ${ }^{3}$, importantes reformas, especialmente en materia de funcionarios y administración local ${ }^{4}$. Se consigue, por fin, llevar al texto de los boletines oficiales normas que traían causa en proyectos anteriores, especialmente el del político D. Antonio Maura ${ }^{5}$. Según el General Primo de Rivera se trataba de corregir los defectos

2 Así señala el profesor Juan Alfonso SANTAMarfa PASTOR: «Y también sabemos que los grandes hitos en la construcción del ordenamiento administrativo se han sentado - icasualmente?- bajo gobiemos conservadores: Dictadura de Narváez, Restauración de Cánovas, Dictadura de Primo de Rivera, en tanto que los cortos períodos liberales o progresistas parecen haber sido estériles para el Derecho público. Así pues, que el Derecho Administrativo ha sido una ciencia y un ordenamiento invariablemente conservador es algo que no puede ser puesto en duda». Vid. de este autor Sobre la génesis del Derecho Administrativo Español en el siglo XIX (1812-1845), Ed. Instituto García Oviedo, Universidad de Sevilla, 1973, págs. 22-23.

3 Vid. Alejandro Nieto GaRcla, Estudios históricos sobre Administración y Derecho administrativo, Ed. INAP, Madrid, 1986, págs. 322-323.

4 Este extremo es puesto de relieve por el profesor Mariano BAENA DEl ALCÁzAR en su obra: Curso de Ciencia de la Administración, vol. I, Ed. Tecnos, 3.' edición, Madrid, 1993, pág. 182.

5 Hay que comprender que durante los años anteriores a la Dictadura el régimen local constituye «un 
más significativos de una Administración corrupta y dominada por el caciquismo, aplicando una «disciplina cuartelera» 6 . Por eso la actividad de la Administración, curiosamente, se jurisdiccionaliza significativamente eliminándose las vías previas administrativas ${ }^{7}$ y naciendo, propiamente, en este momento para el Estado español la doctrina del silencio administrativo con los Estatutos municipal y provincial de Calvo Sotelo ${ }^{8}$. Este proceso de jurisdiccionalización de la vida local es propiciado por el propio Tribunal Supremo que en sentencia de 8 de junio de 1928 (Gaceta de Madrid de 7 de noviembre de 1929) entiende que no es ne-

problema político administrativo clave para la época, que ocupa a regeneracionistas (Costa) y a ensayistas que escriben sobre temas políticos (Ortega y Gasset). Se abre una lucha contra el caciquismo en la que, junto a los citados, participan los hombres más respetables de las distintas tendencias políticas, debiendo citarse al respecto los proyectos de reforma de Sánchez de Toca, Silvela y Maura, que una y otra vez se presentan ante el Parlamento. Pero las Cortes, dominadas por los caciques, rechazan uno tras otro los proyectos, hundiéndose la vida municipal en la miseria, la regresión y el desorden». Vid. Mariano BAENA DEL. AlCAzar, Curso de Ciencia.., op. cit., págs. 180-181.

6 Vid. Alejandro Nieto Garcla, Estudios históricos..., op. cit., pág. 321.

7 Según José Calvo Sotelo la norma fundamental del Estatuto municipal «estriba en sustituir los recursos gubernativos - que desaparecen por completo- por los judiciales, sea ante los jueces ordinarios, sea ante las Audiencias, sea ante los Tribunales contenciosos». La razón de esta opción por un usistema judicial puro" parece estar en la desconfianza en los políticos que gobernaban los ayuntamientos. Asf, el propio Calvo Sotelo señala que: «Había visto, of́do y conocido, los múltiples abusos a que se prestaban los gobernadores civiles, sobre todo en época electoral, en el trance de acorralar a un candidato bienquisto del distrito, o de imponer a un cunero totalmente anónimo; y sentía la firme persuasión de que los funcionarios municipales de cualquier condición y especie ganarían mucho al emanciparse de esa engorrosa tutela, más bien tiranía, siempre que se les abriese amplia y expedita vía judicial para la defensa de sus derechos". Vid. de este autor Mis servicios al Estado. Seis años de gestion. Apuntes para la historia, Ed. Instituto de Estudios de Administración Local, 2." edición, Madrid, 1974, págs. 37-38. Curiosamente sesenta y nueve años después con la LRJPAC se ha producido una reforma similar en la esfera local al casi erradicar los recursos administrativos de este ámbito, si bien las razones son de distinta índole: la inoperatividad del recurso de reposición que en contadísimas ocasiones era objeto de resolución expresa. La doctrina actual postula, mayoritariamente, la reintroducción del recurso suprimido, si bien con carácter potestativo.

8 Es bastante sintomática la conexión entre José Calvo Sotelo y Recaredo FernANdez de Velasco, autor este último de diversos estudios sobre el silencio administrativo. De gran interés es la nota necro16gica que Laureano LOPEz RODO realiza sobre este Catedrático de Derecho administrativo en la Revista General de Legislación y Jurisprudencia 5, 1943, pág. 461: «Acerca del valor doctrinal y la importancia práctica de la producción de FERNÁNDEZ DE VELASCO da idea, no sólo el hecho de haber suscitado nuevos estudios sobre los mismos temas, a base de sus orientaciones, sino también la repercusión alcanzada en el Derecho positivo. Concretamente, su trabajo sobre la acción popular en el proceso contencioso-administrativo, se tradujo en la acogida que de la misma hace el Estatuto municipal, en cuya elaboración intervino: Calvo Sotelo tuvo en FERNÁNDEZ DE VELASCO un íntimo colaborador que le ayudó también en la redacción del Estatuto provincial y en la campaña de conferencias para la difusión y propaganda de ambos textos legales». También es muy indicativo el hecho que CaLvo SOTELO pronuncia el discurso «Semblanza del maestro» en el homenaje a Felipe CLEMENTE DE DIEGo Y GUTtERREz, el día 18 de mayo de 1936, publicado en la obra de este último autor: Dictámenes jurídicos I, Ed. Bosch, Barcelona, 1958. A este ilustre civilista se debe la obra El silencio en el Derecho, Ed. Reus, Madrid, 1925. que sería de cita obligada entre los primeros autores que estudian el silencio administrativo. 
cesario acudir al recurso de reposición previo contra el silencio de la Administración ${ }^{9}$. Se argumenta, de esta forma, que con la doctrina del silencio administrativo «el interesado hace renuncia de una vía administrativa comenzada, que pudiera terminar acaso en un acuerdo, en consonancia con su petición o solicitud, y lo hace en aras de una mayor rapidez en la resolución definitiva de la obligación que se establece o del derecho que se le niega»" ${ }^{10}$.

La burocracia como «forma de corrupción» "tiene, por tanto, un papel significativo en la formación del silencio administrativo el cual se erige como un mecanismo de lucha contra la arbitrariedad gubernativa. Se ha señalado de esta forma que «las normas reguladoras de la vida local» son «las primeras en desarrollar de una manera general la institución del silencio administrativo, quizá debido a que es en dicho ámbito en el que se producían, e incluso hoy se producen, el mayor número de irregularidades» ${ }^{12}$. Sin negar parte de verdad a estas observaciones, debe señalarse, no obstante, que la corrupción en este período, como pudiera serlo en otras épocas, no es privativa de la Administración local como lo demuestran otro tipo de medidas adoptadas por el Directorio militar respecto a los funcionarios de la Administración central del Estado ${ }^{13}$. El problema princi-

\footnotetext{
9 En el mismo sentido la STS de 27 de abril de 1935. No será hasta los años 40 cuando se exigirá el recurso de reposición, acabando con la posibilidad de acudir directamente a la vfa jurisdiccional: vid. SSTS de 20 de enero de 1940, 15 de noviembre de 1941, 18 de enero de 1944 y 20 de marzo de 1945. Como señala Enrique MARTINEZ USEROS en 1947: «Esta tesis de exigir la reposición, aun en el caso del silencio, en el campo doctrinal está basada en la propia naturaleza y finalidad perseguida por el expresado trámite, que es hacer meditar a la Administración y evitar, en lo posible, el pleito». Vid. de este autor: «La teoría del silencio administrativo en el régimen jurídico municipal español» en REVL 32, marzo-abril 1947, pág. 183. Recientemente, si bien con anterioridad a la LRJPAC, Joaquim FERRET I JACAS proponía la supresión de recursos en los supuestos de inactuación de la Administración. Vid. de este autor «El control jurisdiccional de la inactividad administrativa» en DA 208, abril-diciembre 1986, pág. 270.
}

10 Vid. Pedro REDONDO, La teoría del silencio administrativo en la legislación y en la jurisprudencia española, Ed. Reus, Madrid, 1932, págs. 22-23.

11 Sobre la burocracia como forma de corrupción vid. Alejandro NiETo GARCla, Estudios históricos..., op. cit., págs. 321-326, donde se alude precisamente a los intentos frustrados de la dictadura de Primo de Rivera por acabar con la corrupción generada en la Administración liberal.

12 Vid. Emesto Garcla-Trevuano Garnica, El silencio administrativo en el Derecho español, Ed. Civitas, Madrid, 1990, pág. 44. Se señala además que: «Se sintio entonces la necesidad de poner freno a las arbitrariedades cometidas especialmente por los Ayuntamientos, con los que el ciudadano se encuentra en una relación más intensa y directa. Esto es algo fácilmente constatable si se observa lo numeroso de los litigios resueltos por el Tribunal Supremo en relación con demoras o falta de resolución de peticiones (o recursos) dirigidas a las Administraciones localess. Curiosamente la jurisprudencia que cita este autor como anterior a la época de los Estatutos municipal y provincial es referida fundamentalmente a la aplicación del plazo de un año de la Ley de procedimiento a los diferentes departamentos ministeriales de la Administración central.

13 Es significativa, en este sentido, la RO de 17 de septiembre de 1923, dictando disposiciones sobre horas de asistencia a las oficinas y estableciendo sanciones, incluso la cesantía para los que las contravengan; suprimiendo las agregaciones; prohibiendo nuevos nombramientos de personal en los centros mi- 
pal era, según nuestro parecer, judicializar en la medida de lo posible los conflictos entre ciudadanos y entidades locales ${ }^{14}$, reforzando el principio de autonomía local frente a las autoridades gubernativas territoriales ${ }^{15}$ y combatir de esta forma el caciquismo ${ }^{16}$. Esta problemática no era tan acuciante en la Administración central, en teoría más controlada y subordinada al poder del Gobierno de los militares. Es lógico, además, que dada la riqueza de supuestos que plantea la vida local se «experimentase» primero en este ámbito, para generalizarse posteriormente en otros sectores de la Administración, tal como sucedió posteriormente, en la segunda dictadura militar española en el siglo XX. Por otra parte, la presencia de supuestos de silencio administrativo positivo, exclusivamente en el ámbito de relaciones interadministrativas entre el poder central y los entes locales, evidencia con toda claridad un fuerte grado de tutela y control existente hasta entonces, que quiere suavizarse. Con todo debe señalarse que si bien los

nisteriales y sus dependencias, y estableciendo en cada departamento o centro oficial un servicio de reclamaciones (Gaceta de Madrid de 18 de septiembre de 1923).

14 Así, el profesor Nicolás PÉREZ SERrano señala que: «Es decir, que lo que se quería era frenar demaśas de la vida burocrática regularizando su funcionamiento, dando acceso a la vía jurisdiccional, corrigiendo abusos que pudieran existir en la actuación de los organismos municipales, no es otra cosa. Y lo prueba el sentido de amplitud generosa con que el Estatuto y sus Reglamentos hubieron de demarcar y definir toda la materia de lo contencioso-administrativo. Pues ¿qué? ¿Podemos olvidar que fue obra de Calvo Sotelo la implantación en esta esfera de un contencioso objetivo frente al puramente subjetivo de la esfera central, y, además, tantas y tantas reformas para dar agilidad al procedimiento, para facilitar là tramitación? Por ejemplo: gratuidad de los recursos, devolución de oficio de los ingresos indebidos, posibilidad de reclamaciones colectivas, supresión de las alegaciones del artículo 42 de la Ley, allanamiento más fácil del Fiscal a la demanda, responsabilidad con arreglo a la Ley de 1904 sin exigencia del previo requerimiento, no haciendo falta tampoco la consignación en materia de arbitrios, supresión del precepto que obligaba a transcribir en los «Vistos» las disposiciones legales, etc., etc.». Vid. de este autor «EI silencio administrativo ante la doctrina jurisprudencial» conferencia pronunciada en el Colegio de Abogados de Madrid, el día 20 de abril de 1949 en Boletín del Colegio de Abogados de Madrid, julio-octubre 1951, pág. 20.

15 Asf, en la Exposición de Motivos del Estatuto provincial se advierte que: «la ingerencia gubernativa resulta confinada en el mínimo rincón de un caso de necesidad aguda, extremada e imperiosan. Era precisamente el centralismo lo que corrompía la vida local, según los planteamientos de la reforma administrativa planteada por el regeneracionismo conservador de raíz maurista. Vid. Javier TUSEL Go MEZ, La reforma de la Administración local en España (1900-1936), Ed. Instituto de Estudios Administrativos, Madrid, 1973, pág. 173.

16 El profesor Alejandro NIETo GARClA señala como una de las causas que alteran el sistema originario de la jurisdicción contencioso-administrativa: «el desencanto que provoca el control político sobre la Administración, paralizado por un régimen de cacicato en el que los mecanismos políticos y constitucionales no funcionan, ni remotamente, como en teoría están previstos». Vid. de este autor Estudios históricos..., op. cit., pág. 263. Asimismo, el profesor Luis JORDANA DE POZAS indica que: «El Estatuto Municipal ha hecho aplicación de la doctrina del silencio administrativo con gran frecuencia, como medio eficaz de vencer la resistencia de la Administración del Estado a respetar el régimen de autonomía municipal y de prevenir la ineficacia de los recursos establecidos para la protección jurídica de los intereses y derechos particulares». Vid. Luis JORDANA DE POZAS, Derecho municipal (parte orgánica), Biblioteca jurídica de la Escuela Politécnica Matritense, Ed. Librería General de V. Suárez, 1924, pág. 367. 
Estatutos de Calvo Sotelo fueron un intento serio y elogiado de reformar la Administración local «tuvo la desgracia de ser promulgado cuando la representatividad popular era radicalmente marginada» ${ }^{17}$. Por tanto, la suspensión indefinida de elecciones supuso que el caciquismo no solo no se erradico, sino que se consolidó aún más ${ }^{18}$.

De singular interés en este período es el Anteproyecto de Constitución de la Monarquía española de $1929^{19}$. Este texto, salvo notables excepciones, apenas ha sido destacado por la dogmática administrativista, pese a dedicar numerosos preceptos a la Administración pública ${ }^{20}$. En este Anteproyecto se pretendía constitucionalizar la función administrativa, la cual se concibe más allá de una mera ejecución de las leyes, al mismo tiempo que se abordan «los más importantes temas que plantea la actividad de la Administración» ${ }^{21}$. Debe destacarse especialmente el art. 77, en su primer apartado, donde se habla de «la obligatoriedad de la resolución dentro del plazo que la ley señalará como impromogable» y también de que respecto a los recursos contra los acuerdos de la Administración «se arbitrará medio legal para que el silencio administrativo no impida su ejercicio».

En consonancia con tal concepción de la función administrativa el silencio administrativo no es una medida en favor de los administrados, sino que obligaba igual a particulares y a Administración, tal como se constata en la Exposición de Motivos del Estatuto municipal ${ }^{22}$ y así nos lo re-

17 Vid. Florentino-Agustín Díez GoNZÁLEZ, «Estudio preliminar» en Adolfo PosADA, Escritos municipalistas y de la vida local, Ed. Instituto de Estudios de Administración Local, Madrid, 1979, pág. 10.

18 Javier Tuserl Gómez, La reforma..., op. cit., pág. 197.

19 Su título completo es: «Propuestas redactadas por la sección primera de la Asamblea Nacional y leídas en la sesión plenaria de la misma, el 6 de julio de 1979» en Boletín de la Asamblea Nacional, año 11, tomo VI. Nosotros hemos consultado el texto recogido en Leyes políticas españolas fundamentales (1808-1978), recopilación y prólogo de Enrique Trerno Galván, Ed. Tecnos, 2." edición, Madrid, 1984, págs. 152-171.

20 Sí, en cambio, ha sido objeto de estudio por diversos constitucionalistas. En este sentido vid. Francisco FERNÁNDEZ SEGADO, Las Constituciones histónicas españolas (Un análisis histórico-jurídico), Ed. Civitas, 4." edición, Madrid, 1986, págs. 426-432. Un estudio específico puede encontrarse en M. GaRCIA CANALES, El problema constitucional en la Dictadura de Primo de Rivera, Ed. Centro de Estudios Constitucionales, Madrid, 1980.

21 Vid. Sebastián MARTfN-RETORTILO BAQUER, «Presupuestos constitucionales de la función administrativa...", op. cit., pág. 56.

22 En tal Preámbulo se señala que: «Tal autonomía exige un instrumento afinadísimo de responsabilidad, y el Estatuto facilita su exigencia y declaración. En primer término, suprime el trámite previo de recordar el precepto aplicable, que, según la Ley de 5 de abril de 1904, es indispensable para promover una demanda de responsabilidad civil en los casos en que por demora indebida transcurran ciertos plazos precisos, y propone fórmulas que, como la del silencio administrativo y otras, producirán en la práctica inmediata regularización de esta zona del vivir burocrático». 
cuerda la STS de 18 de diciembre de 1929 (Gaceta de Madrid de 27 de agosto de 1930) ${ }^{23}$.

\section{LA LEGISLACIÓN Y LA JURISPRUDENCIA EN LA II REPÚBLICA: EL SURGIMIENTO DE LA CONCEPCIÓN GARANTISTA DEL SILENCIO Y LA IMPLANTACIÓN DEL MECANISMO DE LA DENUNCIA DE LA MORA}

Con la II República española se dejan subsistentes los principios inspiradores de los Estatutos de Calvo Sotelo, aunque se publica una ley en 1935 que los recoge desfigurándolos ${ }^{24}$. Piénsese que, paradójicamente, las reformas municipales de la dictadura llevaron a una cierta democratización de la vida municipal, la cual conduciría finalmente a la caída de la monarquía tras las elecciones municipales de 1931. En el proceso constituyente se impone una concepción estricta de la función administrativa, a través de una enmienda al Proyecto de Constitución republicana realizada por Royo-Villanova «dirigida precisamente a mantener a la Administración pública dentro de la más estricta legalidad ${ }^{25}$ ". Lo que interesaba en aquellos momentos ante todo era robustecer el Poder Judicial frente al Poder Ejecutivo, según se advierte en el Discurso del Presidente de la Comisión Redactora del Proyecto (Jiménez de Asúa) ${ }^{26}$.

Las reformas producidas en esta época alcanzan principalmente aspectos de organización territorial y organizativa, así como de régimen estatutario de los funcionarios. Hasta tal punto que las reformas se dirigen a un intento de contener el gasto público. La brevedad que supone la experiencia republicana no se traduce en grandes reformas de simplificación administrativa, especialmente en materia de procedimiento y recursos jurisdiccionales. No obstante, se pro-

\footnotetext{
23 «[...] conforme a la innovadora doctrina del silencio administrativo, que en este precepto se puntualiza (art. 255 del Estatuto municipal), no ciertamente con el carácter de beneficio particular o facultad ejercitable a voluntad de las partes litigantes, sino como institución o fórmula de garantía, seguridad y fijeza del orden público procesal, que produzca en la práctica una inmediata regularización de esta zona del vigor burocrático, según palabras de la Exposición de Motivos del Estatuto [...]».
}

24 Así, por ejemplo, a los efectos que a nosotros especialmente nos interesan: «viene la Ley del 35, y en algún sentido quiso terminar con las vacilaciones, porque dijo que con respecto a todo género de acuerdos y para recurrir en la vía jurisdiccional hace falta previamente el recurso de reposición. Y la jurisprudencia se viene orientando en este sentido, que, si mal no recuerdo, aplaude don Segismundo Royo-Villanova en su notable obra ya citada». Vid. Nicolás Pérez SerRano, «El silencio administrativo...", op. cit., pág. 17.

25 Vid. Sebastián MARTín-RetortiLlo Baquer, «Presupuestos constitucionales de la función administrativa...», op. cit., pág. 62.

26 El texto del discurso es reproducido fntegramente como anexo en el libro de Jordi SolÉ TURA; Eliseo AJA FernÁNDEZ, Constituciones y períodos constituyentes.... op. cit., pág. 174. 
ducen dos fenómenos, tanto en el plano legislativo como jurisprudencial, que deben ser puesto de relieve y que coinciden con la visión estricta de la función administrativa como reacción lógica a la Dictadura: la primacía del principio de legalidad y de las garantías ciudadanas. En primer lugar comienza a proliferar a través de la legislación sectorial la implantación en ámbitos concretos del silencio, tanto positivo como negativo ${ }^{27}$. En segundo lugar se produce una nueva concepción jurisprudencial del silencio, de la cual es exponente la STS de 8 de abril de 1933 (ref. Ar. 3109), dictada en plena efervescencia republicana. En esta sentencia se proclama que: «hay que tomar como base la naturaleza de que el silencio administrativo tiene que ser una presunción establecida precisamente en favor de los derechos e intereses de los administrados y no en un medio de eludir obligaciones y compromisos de los organismos administrativos, lo que impide darle una interpretación que perjudique a los mismos, a quienes quiso favorecer» 28 .

El período republicano no es, empero, una etapa uniforme, sino que en determinados momentos se vislumbran determinadas concepciones que serán desarrolladas ulteriormente en pleno franquismo. En este sentido, cabe aludir a un hecho significativo en la historia de nuestra institución: la introducción de la denuncia de la mora en el ordenamiento español mediante la Ley municipal, aprobada por Decreto de 31 de octubre de 1935. Ello tiene su origen en una enmienda a la Ley de bases municipal de $1935^{29}$, formulada por el entonces abogado del Estado y diputado a Cortes por la CEDA D. Ramón Serrano Súñer ${ }^{30}$.

27 Son bastante ilustrativos los apéndices normativos que con gran exhaustividad figuran en el trabajo de Julio MASIP ACEVEDO: «El silencio en el Derecho administrativo español» ..., op. cit., págs. 44-60. Así se observa como la mayoría de legislación citada en este trabajo es de principios de los años 30 en sectores tales como: agricultura, beneficencia y sanidad, electricidad, hacienda pública, orden público, trabajo, etc.

28 Así, Ernesto Garcla-Trevijano Garnica señala que: «Esta sentencia daba un giro copernicano a la doctrina jurisprudencial anterior, aunque ciertamente no tuvo una especial repercusión inmediatamente después». Vid. de este autor El silencio administrativo en el Derecho..., op. cit., pág. 51. Debe advertirse, no obstante, que podemos encontrar jurisprudencia anterior en la cual ya se aludía al carácter garantizador del silencio. Así, la STS de 12 de julio de 1928 (Gaceta de Madrid de 2 de enero de 1930): «[...] no sería lícito, en daño del particular, interpretarlo (el silencio) en el sentido de que habría que comenzar a correr desde los ocho días siguientes de expirar el de los cuatro meses, pues ello, sobre no establecerlo de un modo taxativo la ley, envolvería la injusticia, al igualar, en su perjuicio, el valor jurídico de ambas resoluciones, la notificada y la publicada y la que no lo fue, de que la desidia en no resolver por el municipio, a la que impuso un límite el propio Estatuto, se convierta en castigo de quien no hizo sino combatirla tenaz, y al que la misma ley ha querido proteger y salvaguardans.

29 Vid. la enmienda del Sr. Serrano Súñer a la base XXVII del dictamen de la Comisión de Gobernación sobre el proyecto de Ley de Bases para la Ley Municipal en Diario de Sesiones de las Cortes, apéndice $4 .^{\circ}$ al núm. 169.

30 El que posteriormente sería la mano derecha del General Franco durante los primeros años de la dic- 
Tal enmienda si bien no prosperará entonces ${ }^{31}$, se tendrá en cuenta de forma decisiva en la redacción del texto articulado.

La enmienda de Serrano Súñer no es original, como él mismo reconoce ${ }^{32}$, pues sigue en este punto los referentes italianos entonces existentes ${ }^{33}$, asumiendo en substancia el mecanismo procedimental conocido como atto di diffida (acto de advertencia o intimación) ${ }^{34}$. No obstante, introduce una importante novedad:

tadura, cimentando los fundamentos jurídicos del nuevo régimen, realizo durante el denominado «bienio negro» una intensa actividad parlamentaria y política. Como señala él mismo: «Aparte de las cuestiones generales que acuciaban a España, dediqué mi atención especialmente a la Administración Local, el orden público y la defensa de los intereses agrarios de Aragón». Vid. Heleno SAN̄A, El franquismo sin mitos. Conversaciones con Serrano Súñer, Ed. Grijalbo, Colección/80, Barcelona, Buenos Aires, México, DF, 1982, pág. 39. Debe pues tenerse en cuenta significativamente que el contexto en el cual se elabora el proyecto de Ley municipal es del todo diferente al de su discusión, pues entonces «[...] se está ya viviendo la secuela parlamentaria de la revolución de 1934: la izquierda republicana y los socialistas no están en las Cortẹ [...]». Vid. Javier TUSEL. GOMEZ, La reforma de la Administración local..., op. cit., pág. 205.

- 31 La razón por la que no acab6 aceptándose era que no correspondía a las bases el recoger tal innovación, sino al texto que ulteriormente las desarrollara. Vid. la intervención del diputado Sr. Vega de la Iglesia en el debate parlamentario: «La Ley de Bases establece todo aquello que es definidor sustantivo; [...] pero no puede descender al detalle, a la particularización de manifestaciones, qué clases de recursos hayan de existir, cuáles hayan de ser sus plazos, ante qué autoridad hayan de substanciarse, etc., etc. [...] es evidente que la Comisión que el Gobierno nombre para la redacción definitiva de la Ley y la articulación de esta Ley de Bases ha de tener en cuenta toda la legislación anterior, las necesidades y la definición de la Ley de Bases, así como también las discusiones parlamentarias para recoger en el articulado todas aquellas aspiraciones de los Sres. Diputados que hayan aportado a la Comision y a los debates parlamentarios sus iniciativas». Vid. Diario de Sesiones de las Cortes 170, 13 de marzo de 1935, pág. 6.887.

32 Tal posición queda reflejada en la transcripción de su intervención parlamentaria en defensa de la enmienda: "Yo traigo aquí $-y$ naturalmente que tengo que confesar de dónde lo tomo, de la jurisdicción italiana-, yo traigo aquí la innovación de la denuncia de la mora frente al silencio administrativo escueto. [...] la labor personal mía es de organización de ideas, pero técnicamente aquí no hay nada nuevo [...]”. Vid. Diario de Sesiones de las Cortes, 12 de marzo de 1935, págs. 6.886-6.887.

33 Así lo advierte el profesor Nicolás PÉREZ SERRANo, «El silencio administrativo...», op. cit., pág. 15. «Sin fatigar más me remito [...] a los artículos 217 y 218 de la Ley municipal de 1935, en que con respecto a esta última fórmula que mencionaba yo del Estatuto municipal, la del silencio in genere de los cuatro meses, se introdujo por iniciativa del señor Serrano Súñer, con inspiración italiana, una teoría que es la teoría de la mora, que se denuncia, y que al cabo del mes determina la posibilidad de acudir también al Tribunal de lo contencioso». Es bastante significativo que la Junta de Ampliación de Estudios había concedido a Serrano Súñer, una vez acabada su licenciatura de Derecho, una pensión para completar sus estudios en Italia. Vid. Heleno SAÑA, El franquismo sin mitos..., op. cit., págs. 28-29. Otra influencia significativa en Serrano Súner es la de su maestro de Derecho civil D. Felipe Clemente de Diego y Gutiérrez, cuya impronta ya hemos señalado anteriormente respecto a Calvo Sotelo.

34 Este mecanismo fue introducido jurisprudencialmente por la famosa Decisión del Consiglio di Stato de 1902, caso «Longo». Según la misma, transcurrido un cierto plazo («razonable») desde la presentación del recurso, el interesado podía notificar a la Administración un atto di diffida intimando a la misma a que se pronuncie dentro de un cierto plazo, transcurrido el cual, el interesado podía recurrir en sede jurisdiccional, considerando el recurso jerárquico como rechazado. El art. 5 del Texto único de la Ley municipal y provincial, aprobado por RD de 3 de marzo de 1934, en pleno fascismo, recogió en sus- 
la mora se producirá en vía de petición y no de recurso administrativo como sucede en el sistema italiano. Tal extremo se justifica «porque cuando nos encontramos en este recurso (el de reposición) la realidad es que estamos bajo la dirección de un abogado y aquí es innecesario (denunciar la mora)». Este dato es de singular importancia, pues la denuncia de la mora se introduce en vía de petición para alargar los plazos del silencio y evitar los efectos nocivos que producía la teoría del acto consentido ${ }^{35}$. Recordemos que todavía no se había afincado plenamente la interpretación del silencio más favorable a los derechos de los ciudadanos. La enmienda de Serrano Súñer cobra, pues, todo su sentido dentro de la interpretación restrictiva del silencio: éste no se concibe en beneficio de las partes, sino como una medida de orden público procesal. No obstante, cuando años más tarde se consolide la interpretación más garantista, la denuncia de la mora continuará exigiéndose para acceder a la jurisdicción.

\section{EL SILENCIO ADMINISTRATIVO EN EL RÉGIMEN DEL GENERAL FRANCO: ¿UNA TÉCNICA AL SERVICIO DEL «ESTADO ADMINISTRATIVO DE DERECHO»?}

Tras una cruenta guerra civil, el General Franco Bahamonde impone en el Estado español un régimen personalísimo que lleva hasta sus ultimas consecuencias la tradición política de la oligarquía española ${ }^{36}$. La larga duración del franquismo, propiciada por su capacidad de adaptación al curso de los acontecimientos, comportará la existencia de diversas etapas diferenciadas que ponen de relieve el carácter no uniforme de todo este período. En realidad estas etapas «sólo ofrecen un punto en común: el monopolio del poder por parte de Franco» ${ }^{37}$. Este monopolio implica la negación de la Teoría de la división de Poderes, sustituyéndose por una separación de funciones entre diver-

tancia este procedimiento, si bien introduciendo rígidos plazos (en lugar de un plazo razonable a valorar en cada caso: 120 días de la presentación del recurso, 60 días desde la instancia notificada).

35 Según Serrano Súñer: «[...] se daba el caso, muy frecuentemente, y que conocen también muchos Sres. Diputados, de que gentes modestas, gentes vinculadas a la vida de la Administración municipal precisamente, viudas, huérfanos de funcionarios, etc., solicitaban de una Corporación municipal una pensión, un pedimento cualquiera; transcurrían los dos o tres meses, no se resolvía por el Ayuntamiento y, prácticamente, aquello significaba, por virtud de la doctrina del silencio, tanto como la denegación de la petición». Vid. Diario de Sesiones de las Cortes 170, 13 de marzo de 1935, pág. 6.886.

36 Vid. Jordi SOLÉ TuRA; Eliseo AJA FernANDEZ, Constituciones y periodos constituyentes..., op. cit., pág. 3, donde destacan el escaso carácter innovativo del franquismo respecto a la historia del constitucionalismo espariol.

37 Vid. Rafael JiménEZ ASEnSIO, Apuntes para una historia del constitucionalismo español, Zarautz, 1992, pág. 150. 
sos órganos que son controlados en última instancia por el único Poder político existente $^{38}$.

En el denominado «Estado nuevo» ${ }^{39}$ la función legislativa reside en el Jefe del Estado, que contaba desde 1942 con un «instrumento de colaboración», de carácter meramente auxiliar y deliberativo llamado «Cortes españolas». Se eliminaba con ello el «gran obstáculo» que la democracia había supuesto a la acción administrativa ${ }^{40}$. El legislativo era considerado como el «peor de los tres Poderes», según la célebre frase atribuida a V. E. ORLANDO ${ }^{41}$. Este rotundo rechazo del régimen del 18 de julio hacia el Poder legislativo queda algo más atenuado, en cambio, en relación al Poder judicial, si bien se limitará notablemente su ámbito de control que se trasladará en algunos casos a la propia Administración pública.

En apariencia la función judicial «continúa entregada a órganos específicos y prácticamente separados de los que elaboran las normas obligatorias o las aplican en el orden administrativo ${ }^{42}$ (la cursiva es nuestra)». Lo cierto es que como señala el entonces Ministro de Justicia Eduardo Aunós: «La autonomía judicial, antes dictada por la conocida teoría de la división de poderes, se ha esfumado hoy ante el concepto de unidad del Estado» ${ }^{43}$. Requiriéndose que «el

38 Los teoricos del incipiente Estado franquista citan al respecto el discurso de Mussolini dirigiéndose a los magistrados italianos el 30 de octubre de 1939: «En mi concepto no existe una división de poderes en el ámbito del Estado. Para pensar en eso tendríamos que retroceder siglo y medio, y aun entonces se justificaba más desde un punto de vista práctico que doctrinal. En nuestra concepción, el poder es unitario; no hay ya división dę poderes, hay división de funciones». Vid. Luis JORDANA DE POZAS, La reforma administrativa y las revoluciones nacionales. Discurso leído en el acto de su recepción como Académico de número el día 22 de junio de 1941 y contestación del Excmo. Sr. D. José Gascón y Marín, Ed. Real Academia de Ciencias Morales y Políticas, Imprenta de Madrid, s/f, págs. 14-15.

39 Como advierten los profesores Jordi SOLÉ I TURA y Eliseo AJA FERNÁNDEZ, «El franquismo no ha sido propiamente un «Estado nuevo», como pretendian algunos de sus autores [...] al desaparecer la costra propiamente franquista encontramos unos aparatos y unas instituciones que no vienen de ahora, ni nacieron en 1939. O más exactamente: el franquismo superpuso a estos aparatos e instituciones otros de nuevo cuño (como el Movimiento y el sindicalismo vertical), pero acentuando y llevando hasta sus últimas consecuencias los aspectos antidemocráticos ya existentes en los aparatos y en las instituciones anteriores. Puede decirse que toda la inspiración institucional del régimen franquista ya estaba presente en la dictadura de Primo de Rivera». Vid. de estos autores Constituciones y periodos constituyentes..., op. cit., págs. 3-4.

40 «Puede afirmarse con verdad que la Administración padeció la democracia más que se identifico con ella, y al ser barrida ésta, aquella se ha sentido liberada. En el fondo había siempre una oposición, a veces palmaria y cuando no, sorda y constante, entre los hombres de la Administración y los políticos democráticos. Consideraron siempre aquéllos a éstos como intrusos, ineptos y perturbadores. Casi siempre lo eran». Vid. Luis JORDANA DE POZAS, La reforma administrativa..., op. cit., pág. 19.

41 Vid. de este autor Principii di Diritto costituzionale, 6." edición.

42 Vid. Luis JoRdana de POZAS, La reforma administrativa.... op. cit., pág. 15.

43 Vid. el discurso leído el 15 de septiembre de 1943 por el Ministro de Justicia en la solemne apertura de los Tribunales, bajo el título «Abolengo y prestigio de la función judicial», pág. 48. 
Magistrado no se apoltrone ni se entumezca en su función, sino que disponga siempre alerta a una colaboración persistida y vigorosa con el régimen político imperante» ${ }^{44}$. Con la Ley 18 de marzo de $1944^{45}$ se reestablece el recurso contencioso-administrativo ante el Tribunal Supremo que había sido suspendido, según justifica la Exposición de Motivos de la Ley, por las «circunstancias excepcionales en que se hallaba el Poder público durante nuestra Guerra de liberación y la necesidad imperiosa de mantener bajo un mismo fuero la plenitud de poderes» ${ }^{46}$. Además, en materia de personal se sustituye la jurisdicción contencioso-administrativa «por otra más adecuada de orden administrativo» introduciendo un recurso de carácter objetivo ${ }^{47}$, denominado «de agravios», para controlar la actuación administrativa, más que garantizar las posiciones subjetivas de los funcionarios ${ }^{48}$.

Las razones de ello pueden buscarse en la necesidad de garantizar la correcta aplicación por las autoridades inferiores del Derecho emanado desde las altas instancias del Estado. Es decir, los «actos de los inferiores han de estar ajustados a las normas dadas por quien tiene en sí la potestad de dirigir, ordenar, de representar el principio de autoridad» ${ }^{49}$. En este contexto la Ley de

44 Vid. el citado Discurso del Ministro en pág. 47.

45 Como es conocido, durante los primeros años del franquismo existra una auténtica jurisdicción retenida que fue denominada de «agravios» y que fue calificada como «ese semirecurso de casi vía estrecha» por el profesor Nicolás PÉREZ SERRANO en su trabajo «El silencio administrativo...», op. cit., pág. 15. Durante este periodo se sigue aplicando la legislación de procedimiento de 1889 con carácter restrictivo, no admitiendo la figura del silencio administrativo con carácter general en el ámbito de la Administración del Estado. Así, es bastante ilustrativa la Orden de la Presidencia de 25 de octubre de 1951 (BOE de 7 de noviembre de 1951) que cita Femando GarRIDO FaLLA, «La llamada doctrina del silencio administrativo» en $R A P 16,1955$, pág. 89, nota 4. El restablecimiento de la jurisdicción contencioso-administrativa en sede judicial se produjo con una Ley de 1949 en la cual ya se introdujo un supuesto de silencio administrativo. Puede verse sobre el tema a Antonio PÉREZ HERNANDEZ, «El silencio administrativo en la Ley de 18 de marzo de 1944» en Revista de Administración Pública 2, 1950, págs. 131-142.

46

Dicha «suspensión» fue realizada a través de la Ley de 27 de agosto de 1938.

47 Tanto el recurso contencioso-administrativo del Estatuto de Calvo Sotelo como el de la Ley franquista de 1944, responden a un modelo objetivo, basado más en la protección de la «legalidad» que en la tutela de los derechos e intereses de los particulares. Así, el profesor Jesús Gonzálezz Pérez describirá magistralmente algunos años después esta situación: «Lo contencioso-administrativo no persigue el garantizar los derechos subjetivos, sino resolver con arreglo a Derecho las pretensiones formuladas por los particulares. [...] a todo Estado le interesa enormemente que ese Derecho que él ha promulgado, y en el que se han recogido los principios políticos que le inspiran, sea respetado por todos y no quede desvirtuado en manos de sus funcionarios [...]». Vid. de este autor «El texto articulado de la Ley de lo contencioso-administrativo» en $R A P 7,1952$, pág. 203.

48 Según la Exposición de Motivos de la Ley, las razones de esta sustitución es aliviar a los tribunales «de un enojoso volumen de asuntos poco trascendentes y atribuibles más bien a errores de la Administración que a verdaderas conculcaciones de derecho (la cursiva es nuestra)").

49 Vid. la contestación del profesor José GASCÓN Y MARTN en el libro del profesor Luis JORDANA DE POZAs, La reforma administrativa..., op. cit., pág. 39. 
- 1944 establece en su art. 4 «la aplicación del principio del silencio administrativo» respecto al recurso de reposición previo a la vía de agravios. Es muy significativo que el plazo de acceso a esta nueva jurisdicción retenida se compute desde «que se hubiese notificado la resolución denegatoria del recurso de reposición o desde que se entienda desestimado por transcurrir el término señalado sin que haya resuelto la Administración» (la cursiva es nuestra). Se busca con ello no prolongar en el tiempo la existencia de reclamaciones de los funcionarios más que garantizar sus derechos. Esta legislación parece claramente inspirada en la concepción del silencio que había defendido el «arquitecto principal del Estado franquista» Serrano Súñer ante las Cortes republicanas del bienio negro y que ahora tiene una nueva oportunidad de recogerse en las normas de Derecho positivo.

A esta motivación de garantizar la efectiva aplicación del Derecho franquista debe añadirse la necesidad de empezar a legitimar el régimen con mecanismos de control, sean jurisdiccionales o administrativos, que no entren en colisión con los principios del «Estado nuevo». Es por ello que algunos autores proclaman que «no desaparece el denominado Estado de Derecho, pero sí su significación y alcance» ${ }^{50}$. La justicia administrativa se concibe, por tanto, como un «complejo de instituciones encaminadas a garantir la legitimidad de la acción administrativa y el buen uso del poder discrecional de la Administración pública, respecto a los derechos e intereses de las personas físicas y jurídicas sujetas a su potestad» ${ }^{51}$.

La concentración del Poder posibilita, asimismo, la existencia de un Ejecutivo muy reforzado potenciándose claramente los aspectos de eficacia frente a las garantías ciudadanas. De esta forma son frecuentes los procedimientos expeditivos ${ }^{52}$, adoptados de plano, que se caracterizan en muchos casos por la ausencia de audiencia a los interesados ${ }^{53}$, así como la limitación de dicho

50 Vid. la contestación del profesor José GASCÓN Y MARtí en el libro del profesor Luis JoRDANA DE POZAS, La reforma administrativa..., op. cit., pág. 43.

51 Vid. la contestación del profesor José GASCÓN Y MARŔN en el libro del profesor Luis JORDANA DE PozAs, La reforma administrativa..., op. cit., pág. 43.

52 Así, el profesor Joaquín Tornos MAS cita el ejemplo de la Exposición de Motivos de la Ley de 30 de septiembre de 1940 por la que se creaba la Fiscalía de Tasas, según la cual se insiste en la necesidad de actuar con rapidez y ejemplaridad «sin que los trámites jurídicos puedan servir de escudo a los infractores, maestros en argucias de perturbar o burlar la justicia con trámites o retrasos». Vid. de este autor "Comercio interior y exterion en Sebastián MARTiN-ReTORTLLo BAQUer (ed.), Derecho administrativo económico II, Ed. La Ley, Madrid, 1991, pág. 569.

53 En este punto cabe citar las sanciones de plano que recogía el antiguo art. 137.2 del Decreto de 31 de enero de 1947, por el cual se aprobaba el Reglamento de procedimiento administrativo del Ministerio de Gobernación, que fue objeto de estudio por Lorenzo MARTEN-RETORTLLO BAQUER, Las sanciones 
trámite ${ }^{54}$. Se señala entonces que «se ha tratado de abreviar los trámites de los expedientes reduciendo los plazos, prescindiendo de actuaciones innecesarias o complicadas y creando una tramitación especial de los expedientes, denominada «tramitación abreviada» ${ }^{55}$. Por tanto, la celeridad y rapidez en la tramitación y resolución de los procedimientos deviene, al menos sobre el papel, un principio del procedimiento, si bien existen escasos mecanismos, desde la perspectiva del ciudadano, para hacerlo efectivo ${ }^{56}$. El silencio se concibe como uno de estos mecanismos «encaminado a mejorar los procedimientos, y no a favorecer la negligencia de la Administración ni de los particulares». El Tribunal Supremo y el Consejo de Estado vuelven por tanto a la interpretación más restrictiva del silencio ${ }^{57}$.

de orden público en el Derecho español I, Ed. Tecnos, Madrid, 1973. Ahora bien, hay que precisar que la sanción de plano «se trata de una técnica perfectamente habitual en todo nuestro Derecho histórico -no sólo en el régimen político anterior-y que, pese a su manifiesta incompatibilidad con el artículo $24 \mathrm{CE}$, llego a mantenerse durante los primeros años de vida del nuevo régimen, bien que en relación con hechos acaecidos con anterioridad, recibiendo en tales casos la santificación de la jurisprudencia del Tribunal Supremo». Vid. Juan Alfonso Santamarfa PASTOR; Luciano Parejo Alfonso (eds.), Derecho administrativo (La jurisprudencia del Tribunal Supremo), Ed. CERA, Madrid, 1989, pág. 225. En todo caso, esta tendencia a la ausencia de trámite de audiencia se reafirma plenamente con el régimen del General Franco.

54 Este fenómeno de limitación del trámite en los reglamentos de procedimiento posteriores a 1947 es analizado por el profesor José GASCON Y MARÍN, El procedimiento administrativo, sus modalidades y problemas (Cursillo de tres lecciones explicadas en la Universidad de Deusto los días 7. 8 y 9 de febrero de 1955), Ed. Patronato de la Universidad d Deusto, s/f. Así, este autor señala en la pág. 39 como «el criterio modemo en los más recientes reglamentos no es muy favorable a la amplitud de la audiencia a conferir a los interesados». Entre los diversos ejemplos cita el art. 42 del reglamento del Ministerio de Industria de 7 de septiembre de 1954 del cual señala que está limitado el derecho de audiencia «a pesar de no estar derogada la Ley del 89." Entre otros aspectos quedaban sin contradicción de los interesados desde la propuesta de resolución a diversos informes jurídicos, así como los documentos que se considerasen reservados.

55 Vid. José María VILLAR Y ROMERo, Derecho procesal administrativo, 2." edición aumentada y corregida, Ed. Revista de Derecho Privado, Madrid, 1948, pág. 60.

56 Vid. José María VIULAR y ROMERo, Derecho procesal..., op. cit., pág. 61.

57 En esta línea son significativos los considerandos de la STS de 8 de mayo de 1946 (ref. Ar. 583): «Que si a raíz de ser incorporada a nuestro Derecho vigente la doctrina del silencio administrativo, pudo por alguien sostenerse que su finalidad no era otra que la de favorecer a los particulares enfrentados con la Administración, al poner trabas a ésta, impidiendo que pudiera oponerse, indefinida y pasivamente a las justas pretensiones de aquéllos, basta fijarse para no aceptar tal pensamiento, en que la interpretación auténtica de la reforma, contenida en la exposición de motivos del Estatuto municipal de 8 de marzo de 1924, en nada favorece aquella opinión, puesto que con referencia a la novedad evocada, sólo afirma «que ésta y otras fórmulas producirán en la práctica, inmediata regularización de esta zona del vivir burocrático». Por ello se concluye que el silencio administrativo está «encaminado [...] a mejorar los procedimientos municipales». En esta interpretación tendría un papel significativo el Consejo de Estado según señala Antonio PÉREZ HeRnÁNDEZ, «El silencio administrativo en la Ley de 18 de marzo de 1944» en RAP 2, 1950, págs. 135-138. En sentido parecido, vid. UBIERNA EUSA quien amparándose en esta doctrina jurisprudencial señalaba que: «la teoría del silencio administrativo, implantada en el artículo 268 (del que a su tiempo se hablará), no se halla establecida exclusivamente en favor de los particulares, sino que comprende también a la Administración [...]". Vid. de este autor De lo contencioso-administrativo, Madrid, 1948, pág. 271. 
LA EVOLUCIÓN HISTÓRICA DEL STLENCIO ADMINISTRATIVO:..

Además, el factor tiempo en el procedimiento quedará condicionado por una Administración depurada de funcionarios contrarios al régimen. Ello unido a las bajas naturales producidas por una guerra civil llevan a la existencia de una burocracia improvisada, sin una formación técnica precisa. Circunstancia que influirá probablemente en la eficacia y rapidez de la Administración pública de entonces. Por último, debe señalarse, además, que se excluye en diversa normativa la posibilidad de interponer recursos administrativos o jurisdiccionales contra determinadas decisiones administrativas que se califican en determinadas ocasiones como actos políticos o de gobierno, eludiéndose cualquier forma de control sobre ellos.

En aquellos momentos si bien es cierto que la legislación sobre procedimiento de algunos Ministerios incorpora algunos supuestos de silencio administrativo ${ }^{58}$, podía intuirse que la Administración continuaba reservándose cierto grado de discrecionalidad en la tramitación del procedimiento con el expediente de solicitar informes o documentos a centros del propio Ministerio o de otro departamento. No obstante, esta posibilidad será rechazada por algunos autores al entender que: «Permitir la suspensión sine die sería colocar la aplicación de la doctrina del silencio en manos de la Administración, que podría, a su antojo, aplicarla o no, valiéndose para desvirtuarla del medio de pedir informes o documentos, aplazando así indefinidamente la resolución» 59 .

A partir de 1950 el régimen sale del bloqueo internacional impuesto en los primeros años por su colaboración con el Eje en la II Guerra Mundial. En aquellos momentos sucede un acontecimiento de gran magnitud en la historia de nuestro Derecho administrativo: la aparición de la Revista de Administración Pública. Bajo sus siglas $(R A P)$ se aglutinará una nueva generación de autores que imprimirán una profunda renovación en nuestro panorama bibliográfico-doctrinal. Desde este relevo generacional se inicia un proceso de lucha por el Derecho y contra las arbitrariedades administrativas. Estos autores prescindiendo de la falta de legitimidad del régimen, en cuya construcción no han intervenido, sientan las bases doctrinales de lo que ha venido a denominarse el «Estado administrativo de Derecho» ${ }^{60}$.

58 Así de la primera época es el art. 116 del Reglamento de procedimiento administrativo del Ministerio de Gobernación, aprobado por Decreto de 31 de enero de 1947, (BOE 143, de 23 de mayo de 1947).

59 Vid. Segismundo Royo-VILLANOVA Y FERnÁndEZ CAVADA, «El procedimiento administrativo como garantía jurídica» en REP 48, 1949, pág. 98, donde comenta tal posibilidad al hilo de una eventual interpretación del art. 107 del Reglamento de procedimiento del Ministerio de Gobernación.

60 Vid. Fernando Garrido Falla; José María Fernández Pastrana, Régimen jurídico y procedimiento de las Administraciones públicas (Un estudio de la Ley 30/1992). Ed. Civitas, donde la pág. 26 se encabeza con el significativo epigrafe titulado «La revolución legislativa de los años cincuenta: el Estado administrativo de Derecho». También es importante poner de relieve que la RAP dedica un núme- 
Como ha advertido NiETo García: «el Derecho administrativo tenía un objeto concreto y excitante: el establecimiento de un Estado de Derecho, viable y eficaz aun dentro de un régimen autoritario" 61 . Durante este período los autores se esfuerzan en buscar mecanismos de control frente a la actuación administrativa acudiendo más a otras doctrinas y ordenamientos que al propio ordenamiento interno ${ }^{62}$, desmarcándose con claridad de los referentes tradicionales que asumían los autores más identificados con el régimen los cuales venían a identificar el Derecho administrativo con la realidad política y filos6fica del país ${ }^{63}$. A través de esta flexibilidad y permeabilidad del ordenamiento interno se busca la defensa del individuo frente a la Administración, concebida como única expresión del poder ${ }^{64}$. El referente a seguir sería en mayor medida la doctrina italiana que había construido desde dentro del régimen un notable sistema de garantías frente a la Administración pública. La «bendición» que Mussolini había realizado del sistema de justicia administrativa y Derecho administrativo existentes en Italia ante la IV Sección de un Consiglio di Stato presidido por Santi Romano ${ }^{65}$, supone una formidable «carta de presentación»

ro monografico el núm. 6 (septiembre-diciembre 1951) a «El Estado de Derecho». Posteriormente encontramos entre los trabajos más relevante el del profesor Rafael ENTRENA CUESTA: «Notas sobre el concepto y clases de Estado de Derechom en RAP 33, septiembre-diciembre 1960, págs. 31-45; y el del profesor Lorenzo MARTIN-RETORTILO BAQUER, «El genio expansivo del Estado de Derecho» en RAP 47, mayo-agosto 1965.

61 Vid. Alejandro NiETo GaRcta, Estudios históricos..., op. cit., pág. 8.

62 Vid. José Luis CaScajo CASTro, «La lucha por el Estado de Derecho» en Sistema 17-18, abril 1977, pág. 162.

63 Son muy expresivas las palabras del profesor Segismundo Royo-Villanova y FERnÁndez CAVADA, «El Derecho administrativo es el reflejo de la filosofía jurídica y política del mismo. La Administración y sus instituciones jurídicas no constituyen un mundo aparte, sino que son un sector, un aspecto de la vida y del derecho de la comunidad política. De aquí que todo cambio fundamental operado en la Constitución política haya de repercutir necesariamente en la Administración públicas. Vid. de este autor «Lo contencioso-administrativo en los Estados totalitarios» en Revista General de Legislación y Jurisprudencia, octubre 1941, pág. 307.

64 Vid. Elisenda MALAREt I GarClA, «Le Droit administratif espagnol entre l'ordre juridique national et l'ordre juridique communautaire» en Gérard MARCou (ed.), Les mutations du Droit de l'Administration en Europe. Pluralisme et convergences, Ed. L'Harmattan, París, 1995, pág. 102, nota 7, pág. 131. Esta autora pone significativamente de relieve cómo la concepción «anacional» del Derecho administrativo puede encontrarse en la polémica doctrinal desarrollada por Manuel BALLBÉ PRUNES, «Derecho administrativo» voz de la NEJ, tomo I «Derecho», Ed. Francisco Seix, Barcelona, 1950, págs. 55-82 y Femando GarRIDo FALLA, «Sobre el Derecho administrativo y sus ideas cardinales» en RAP 7, 1952, págs. 11-50.

65 Así, Mussolini en su discurso señalaría que: «Cuando vosotros, honorables señores del Consejo de Estado, anuláis actos administrativos viciados de incompetencia, de violación de ley, de abuso o desviación de poder, no creáis obstáculos a la buena marcha de la Administración fascista, sino que la llamáis y reintegrais a sus fines esenciales». Estas palabras serían reproducidas al final del trabajo de Segismundo Royo-VILlanOVA Y FERNÁNDEZ CAVADA, «Lo contencioso-administrativo en los Estados totalitarios» ..., op. cit., pág. 339. Esta conexión se pone de relieve con la lectura de la Exposición de Motivos 
para las doctrinas italianas ante las autoridades franquistas que no ven con tanto recelo la importación de estas tesis extranjeras.

Durante los inicios de los años 50 se promulgan diversas disposiciones que son una continuación del sistema construido en años anteriores pero que empiezan a ser cuestionadas de forma decidida por esta nueva y brillante generación de autores. En este sentido, el Texto refundido de la Ley de lo contencioso-administrativo por Decreto de 8 de febrero de 1952, que se mueve en los estrechos márgenes de las leyes de 1888 y de 1944, no avanza apenas en la implantación de verdaderos mecanismos de control jurisdiccional de la Administración pública. La doctrina administrativa con las herramientas del Derecho procesal evidenciará entonces la necesidad de ampliar el ámbito del recurso contencioso-administrativo y regular desde otras premisas técnicas este ámbito procesal ${ }^{66}$, gestándose entonces un proceso de reforma que culminaría unos años más tarde ${ }^{67}$.

Cuestión similar sucede con los reglamentos de procedimiento administrativo dictados por diversos Ministerios que fragmentan aún más el régimen de recursos y del silencio que se regula generalmente con carácter negativo ${ }^{68}$. En este contexto parece sobresalir el art. 28 del Reglamento de procedimiento del Ministerio de Trabajo, aprobado por Decreto de 2 de abril de 1954. Con él se implantaba en el ámbito de este Ministerio la regla general del silencio positivo. Para Garrido Falla estábamos ante un artículo que calificaba «sencillamente, revolucionador» ${ }^{69}$, si bien debe destacarse que en la Administración laboral existía cierta tradición en considerar estimatorio el silencio adminis-

de la Ley de la jurisdicción contencioso-administrativa de 1956 que, unos años más tarde, vendría a señalar: «[...] cuando la Jurisdicción contencioso-administrativa anula los actos ilegítimos de la Administración, no tan sólo no menoscaba su prestigio y eficacia, sino que, por el contrario, coopera al mejor desenvolvimiento de las funciones administrativas y afirma y cimenta la autoridad públican.

66 Vid. Jesús GonzÁlez PÉREZ, «El texto articulado de la Ley de lo contencioso-administrativo» en RAP 7, 1952.

67 Es significativo que a finales de ese mismo año se dicta una Orden del Ministro de Justicia de 17 de noviembre de 1952, por la que se constituye una Comisión encargada de redactar en el plazo máximo de seis meses un anteproyecto de reforma de la Ley sobre el ejercicio de la jurisdicción contencioso-administrativa (BOE 324, de 19 de noviembre de 1952). En esta Orden se habla de la «imperfección técnica de nuestro régimen contencioso-administrativo actual».

68 Así, pueden citarse los arts. 63 y 84 del Reglamento de procedimiento administrativo del Ministerio de Industria, aprobado por Decreto de 7 de septiembre de 1954; art. 28 del Reglamento de procedimiento del Ministerio de Trabajo, aprobado por Decreto de 2 de abril de 1954 (BOE 128, de 8 de mayo de 1954); así como diversas Ordenes en el Ministerio de Educación Nacional y el de Obras públicas.

69 Vid. de este autor «El nuevo reglamento de procedimiento administrativo del Ministerio de Trabajo» en Revista de Derecho del Trabajo 2, 1954, págs. 31-32. Es más, llega a señalar que «Ejemplos de silencio administrativo con valor positivo no existen en nuestro ordenamiento». 
trativo ${ }^{70}$. Según nos cuenta la Exposición de Motivos uno de los principios que inspiraban la redacción del reglamento era la rapidez en la tramitación que respondía no sólo a necesidades de buena administración, sino que especialmente en el ámbito de este Ministerio «se ventilan intereses que directamente afectan a las clases económicamente débiles». Con este tipo de disposiciones el régimen pretendía continuar disponiendo del apoyo popular que había obtenido durante la guerra y que empieza a convertirse en un apoyo pasivo ${ }^{71}$. En realidad, estábamos ante una de las manifestaciones paternalistas del régimen que si bien eliminaba toda forma de movimiento obrero, declarando superada la lucha de clases, producía «un cierto desarrollo de la legislación laboral, cuyo principal artífice - no sin cierta demagogia - fue José A. Girón desde el Ministerio de Trabajo durante dieciséis años" ${ }^{72}$. Desarrollo normativo cuya efectividad y aplicación real estaría condicionada, indudablemente, por los efectos que había generado en el país la postguerra y la política económica del período autártico ${ }^{73}$, y de los que entonces se estaba empezando a salir.

Sin embargo, pronto surgirán nuevas normas de gran calidad técnica en las que empezaban a reflejarse las aportaciones de la doctrina. En este sentido, el Reglamento de servicios de las corporaciones locales (RSCL), aprobado por Decreto de 17 de julio de 1955 (BOE de 15 de julio de 1955), recoge en sus articulados «las conclusiones de la Ciencia jurídico-administrativa», según reza

70 Así, Eugenio PÉREz Botua nos recuerda que: «en materia de despidos por crisis (art. 3, D. 26 de enero de 1944), aprobación de reglamentos de régimen interior (Ley 16 octubre 1942, art. 17) y propuesta de salarios superiores a los mínimos legales (art. 1, D. de 16 de enero de 1948, que amplía el de 31 marzo 1944, sobre política de salarios). Dichas disposiciones consideran aprobatorio el silencio administrativo. López Teijeiro señala los precedentes en la legislación de Comités paritarios y Jurados mixtos». Vid. de aquel autor «El procedimiento administrativo del Ministerio de Trabajo como Derecho laboral adjetivo» en Revista de Derecho del Trabajo 9, 1955, pág. 59, nota 16.

71 Vid. Javier Tusell, La dictadura..., op. cit., pág. 171.

72 Vid. M. Carmen Garcla-Nieto; Javier M. Donezar, La España de Franco 1939-1973, Ed. Guadiana, Madrid, 1975, pág. 16.

73 Como advierte el profesor y magistrado Francisco GoNZÁLEZ NAVARRO: «La reforma estuvo vigente cuatro años, desapareciendo al entrar en vigor la LPA. Murió sin pena ni gloria, y ninguna voz se alz6 en defensa de la permanencia del sistema, síntoma claro de que las cosas no habían funcionadom. Vid. Francisco GonzÁlez NaVARRo; Jesús GonzÁlez PÉrez, Régimen juridico de las Administraciones públicas y procedimiento administrativo común (Ley 30/1992, de 26 de noviembre), Ed. Civitas, Madrid, 1993, pág. 579. La escasa trascendencia que debió tener el silencio positivo implantado por el Reglamento del Ministerio de Trabajo parece confirmarse además por la escasa conflictividad que suscitó el mismo ante los tribunales. Así nosotros tan sólo hemos localizado un pronunciamiento jurisprudencial que hiciera expresa aplicación del precepto citado: STS de 15 de febrero de 1960 (ref. Ar. 772). No obstante, Jesús GonzAlez PÉREZ, al referirse a este supuesto de silencio positivo del Ministerio de Trabajo, explicaba que: «[...] la práctica administrativa parece haber demostrado los espléndidos resultados que con la misma (con la consideración del silencio positivo) se ha conseguido, al obligar a los distintos órganos del Ministerio a resolver los expedientes dentro de plazo [...]. Vid. de este autor Derecho procesal administrativo, tomo Il, Madrid, 1957, pág. 360. 
LA EVOLUCIÓN HISTÓRICA DEL SILENCIO ADMINISTRATIVO: ...

en su Exposición de Motivos. La importancia de este Reglamento en el funcionamiento cotidiano de nuestras Administraciones municipales ha sido extraordinaria, hasta el punto que muchos de sus planteamientos han llegado prácticamente intactos hasta nuestros días. El Reglamento no se limita a regular los modos o formas de gestión de los servicios públicos municipales, como parece indicar su denominación, sino que abarca las distintas formas de actividad de la Administración pública. Se establece en el mismo una regulación general de las licencias municipales, implantándose el silencio positivo como mecanismo de respuesta a la inactividad administrativa. El procedimiento establecido señala un plazo de dos meses para resolver la solicitud a partir de su presentación en el Ayuntamiento. Si transcurriera ese plazo sin resolución el particular acudirá a la Comisión Provincial de Urbanismo o, en su defecto, a la Comisión Provincial de Servicios Técnicos, habiendo de transcurrir un mes sin la notificación del acuerdo expreso, para entenderse producido el silencio positivo.

La doctrina se mostró dividida sobre la regulación del silencio contenida en el RSCL. Para unos autores el Reglamento podía traer a confusión a muchas corporaciones locales pues éstas «no habrán creído que en un reglamento de servicios se establece un procedimiento en materia de obras», al mismo tiempo que en algunas provincias no funciona la Comisión Provincial de Urbanismo ni tampoco lo hace debidamente la Comisión Provincial de Servicios Técnicos ${ }^{74}$. Se advertía, en estas circunstancias, de los peligros que representaba la adquisición de licencias de obras por silencio positivo sobre todo en aquellos casos en que hubiera manifiesta contradicción con las Ordenanzas de construcciones ${ }^{75}$. Desde esta perspectiva, el silencio positivo convertía al particular en administrador de intereses públicos y por ello se veía con recelo y desconfianza. No obstante, desde un planteamiento distinto, otros autores consideraron que «estas razones no son aplicables en el supuesto de licencias de policías, ya que «por medio de estas licencias, no se le confiere al particular algo que previamente perteneciera a la Administración, sino que simplemente se le faculta para el ejercicio de un derecho del que ya era titular» ${ }^{76}$.

Otro punto polémico que introducía el RSCL era la necesidad de acudir a la Comisión de Urbanismo o, en su defecto, a la Comisión Provincial de Servi-

74 Vid. Manuel Clavero Arévalo, «El reglamento de servicios de las Corporaciones locales de 17 de junio de 1955» en RAP 19, 1956, págs. 287-301, también publicado en la obra del mismo autor Estudios de Derecho administrativo, Ed. Instituto García Oviedo, Universidad de Sevilla y Civitas, Madrid, 1992, pág. 307, de donde cogemos la referencia.

75 Vid. Manuel Clavero ArÉvalo, «El reglamento de servicios...», op. cit., pág. 307.

76 Vid. Rafael ENTRENA CUESTA, «Las licencias en la legislación local» en REVL 107, septiembre-octubre 1959, pág. 668. 
cios Técnicos. Para Fernando AlBI ChOlBI en realidad ello «equivale a un verdadero recurso de alzada, aunque solamente para los casos de silencio" 77 . Solución que dudosamente podía introducir un reglamento, pues el art. 361 de la Ley de régimen local de 1950 establecía la inmediata ejecutividad de los acuerdos locales. No pudiéndose buscar para ello una cobertura legal en el art. 374.3 de la misma Ley, pues la misma se limitaba a prever la existencia de supuestos de silencio administrativo en determinadas materias a través de preceptos especiales. La intervención de estos órganos era, por lo demás, perfectamente coherente en un sistema eminentemente centralista donde la «autonomía municipal» era una mera proclamación rituaria ${ }^{78}$. Según veremos más adelante, la jurisprudencia precisará la naturaleza de esta intervención en el ámbito municipal, considerándola ajustada al sistema legal vigente.

Hacia 1956 se produce un importante acontecimiento en las mismas entrañas del régimen: significados miembros de Falange salen del Gobierno o son relevados a puestos de menor importancia, siendo desplazados por tecnócratas con una preparación más elevada. Consecuencia de este importante relevo en las jefaturas de los Ministerios, será la creación en los años cincuenta de un importante bloque de normativa de gran rigor técnico en donde se intentan potenciar las garantías ciudadanas, suavizándose el totalitarismo imperante en los primeros tiempos del franquismo. Por eso curiosamente durante este momento en el Estado español la denominada doctrina del silencio administrativo se generaliza a todas las Administraciones públicas culminando las reformas efectuadas a la Administración local durante la dictadura del general Primo de Rivera, al dictarse los Estatutos provincial y municipal. De esta forma, encontramos un importantísmo bloque normativo sobre la materia al dictarse la Ley de 27 de diciembre de 1956, de la jurisdicción contenciosa-administrativa (LJCA).

Como pone de relieve GarCí de ENTERRÍ la LJCA fue consecuencia del acierto del entonces Ministro de Justicia Antonio Iturmendi Bañales ${ }^{79}$ de en-

77 Vid. Fernando Albi Cholbi, Tratado de los modos de gestión de las Corporaciones locales, Ed. Aguilar, Madrid, 1960, pág. 67.

78 Como advierte el profesor Alejandro NIETO GARCía, el municipio como ente natural, que tenía un ilustre antecedente en la obra de Calvo SOTELo, era una mera ficción y la autonomía municipal una declaración sobre el papel. La Ley de régimen local enumeraba una lista de competencias upropias» del municipio, pero a la vez se admitía sin reservas las competencias concurrentes del Estado, que eran las que primaban en caso de conflicto. Vid. de este autor «La organización local vigente: uniformismo y variedad» en Sebastián MARTtN-RETORTLLO BAQUER (ed.), Descentralización administrativa y organización política, tomo II, La centralización española vigente, Ed. Alfaguara, Col. «Hombres, hechos e ideas», Madrid, 1973, págs. 63-64.

79 El Ministro Iturmendi que fue uno de los ministros franquistas que más tiempo estuvieron en el poder era sun claro exponente de las preferencias de Franco en nombrar ministro de Justicia o presidente de las Cortes a hombres procedentes del antiguo tradicionalismo no dinástico o del integrismo católicon. Es 
comendar su redacción «a dos Profesores de extraordinaria capacidad y claridad de ideas y de pluma poco comunes, los Profesores Manuel Ballbé y Jesús GoNZALEZ PÉrEZ; y -segundo acierto- haber confiado plenamente en su trabajo y hacerlo hasta que se convirtió en la Ley de 27 de diciembre de $1956{ }^{80}$. Lo cierto es que la opción que realiza el Ministro entra claramente en sintonia con la necesidad de legitimar al régimen como un Estado de Derecho, desplazando el control parlamentario, prácticamente inexistente entonces ${ }^{81}$, hacia un control ejercido por jueces ${ }^{82}$ que se suponían afectos al régimen y que respondieron en gran medida a tales expectativas ${ }^{83}$.

Con la LJCA nace en 1956 nuestro moderno Derecho procesal administrativo, recogiendo las bases teóricas formuladas un año antes por GONZÁLEZ PÉRE Z ${ }^{84}$.

bastante significativa su experiencia con la Administración Local ya como abogado del Estado ya durante su época como Director General de Administración Local, etapa en la que creó el Instituto de Estudios de Administración Local y reorganizo los Cuerpos de funcionarios de dicha Administración. Vid. sobre su perfil Equipo MUNDO, Los 90 Ministros de Franco, 3." ed., Ed. DOPESA, Madrid, 1971, págs. 167-168.

80 Vid. Eduardo Garcla de ENTERrfa Martínez-CaRANDE, Democracia, jueces y control de la Administración, Ed. Civitas, Madrid, 1995, pág. 39. Este mismo autor ha destacado la gran influencia que tuvo en la construcción del Derecho administrativo moderno el magisterio del profesor Manuel Ballbe Prunes. Vid. Ia Nota necrológica publicada en la RAP 36, septiembre-diciembre 1961. Así, en las págs. 8-9 se señala que: «Los Reglamentos de Bienes y de Servicios de las Corporaciones locales, la Ley del Suelo, la Ley de la jurisdicción contencioso-administrativa, la Ley de Procedimiento administrativo, la Ley especial del Municipio de Barcelona, son seguramente, en lo mejor de todas ellas, la obra casi personal de Ballbé, «cuya sutileza y vigor -dijo públicamente uno de nosotros, mientras él vivía y refiriéndose a una de esas Leyes- no es difícil descubrir expresos en el mismo texto legal».

81 Es fundamental en este punto el estudio de Ángel GarRoRENa MORALES, Autoritarismo y control parlamentario en las Cortes de Franco. Apuntes para un análisis crítico. Ed. Universidad de Murcia, Publicaciones del Departamento de Derecho Político, Murcia, 1977. Son harto elocuentes, entre otros los siguientes epígrafes de esta obra: «Los procuradores y la labor de fiscalización: sociología de una función frustrada», «La actitud del Gobierno: "como un arzobispo en su catedral"», «Al borde del letargo: una curva inversa a la de ruegos y preguntas".

82 Ya advertía en los primeros años del régimen Carlos GAP.CfA OviEDo que: «Es más: si cabe, es aún más necesario el recurso contencioso en el Estado totalitario y en el Estado liberal (sic: en vez de " $y$ " póngase "que" para una correcta comprensión de la cita), pues la falta de control en un Parlamento, el régimen de censura de prensa y la disminución general del derecho de crítica política imponen, para neutralizar peligros provinientes en estas circunstancias, el reforzamiento de las garantías administrativas y judiciales en favor de los derechos del particular». Vid. de este autor «Consideraciones acerca del recurso contencioso administrativo en el Estado totalitarion en Revista de la Facultad de Derecho de la Universidad de Madrid 8, 9, 10 y 11, 1942, homenaje al profesor José Gascón y Marín, pág. 80.

83 Vid. Francisco José BASTIDA FREUEDO, Jueces y franquismo..., op. cit.

84 En 1955 se publica la 1." edición de Derecho procesal administrativo. El procesalista Jaime GuASP advierte en el prólogo que: «Esto no es otro tratado sobre el contencioso-administrativo; es hasta ahora el único. Aquí no se trata de modernizar, simplemente, manuales anticuados, desde el punto de vista cronológico, o arcaicos desde la perspectiva de la terminología. Aqui se hace otra cosa: un lenguaje nuevo, 
Los redactores de la Ley, utilizando las herramientas de la Ciencia procesal, cuestionan el carácter revisor de la jurisdicción contencioso-administrativa, reestableciéndolo a sus justos términos: la existencia de un acto administrativo como presupuesto de admisibilidad de la acción y no como el objeto del proceso contencioso-administrativo. Se mantiene, por tanto, el carácter revisor pero desde un nuevo planteamiento. Lo contencioso-administrativo se articula desde la idea procesal de la satisfacción de pretensiones. Desde esta nueva perspectiva, «el acto no debe erigirse como obstáculo que impida a las partes someter sus pretensiones a enjuiciamiento de la Jurisdicción Contencioso-administrativas (Exposición de Motivos de la LJCA). Para ello se generaliza el régimen del silencio administrativo negativo, aplicable por tanto a todas las Administraciones públicas, a través del art. 38 de la LJCA. Se recogen, en definitiva, las demandas que venía formulando la doctrina de una nueva regulación del silencio administrativo ${ }^{85}$.

Esta regulación general del silencio viene a recoger fundamentalmente el mismo esquema previsto ya en el año 1935 en la legislación local. La misma distingue dos sistemas: en vía de petición o instancia existe el mecanismo de la denuncia de la mora, mientras que en vía de recurso el silencio se produce automáticamente, es decir, por el mero transcurso del tiempo. Con el art. 38 de la LJCA se extiende la aplicación del silencio a toda la Administración del Estado, superándose la fragmentación del instituto que había producido la existencia de diversos reglamentos ministeriales. No obstante, la LJCA no se limita a reproducir, con leves variaciones en los plazos, la regulación del silencio contenida en la legislación local para darle un alcance general. La superioridad técnica del nuevo texto legal en relación con sus precedentes se detecta en el carácter de mero presupuesto procesal que adquiere el silencio administrativo en relación al acceso a la jurisdicción. En efecto, el silencio administrativo se produce según el art. 38 «al efecto de formular frente a esta denegación presunta el correspondiente recurso administrativo o jurisdiccional, según proceda, o esperar la resolución expresa de su petición».

La LJCA opta claramente por entender el silencio como un mecanismo destinado a favorecer al interesado, en vez de un medio de agilización de la actuación

un sistema nuevo, unos resultados nuevos. La obra de GonzÁlez. PÉREZ no continúa, sino destruye las anteriores: a partir de ella, se abre un nuevo camino en el cultivo de los temas de lo contencioso-administrativo, y cualquier retroceso que quiera imaginarse habrá de ser automáticamente descalificado por anticientífico».

85 A título de ejemplo, cabe citar el trabajo del profesor Laureano LÓPEZ RoDó, con el expresivo título de: «Necesidad de una nueva regulación del silencio administrativo en nuestro Derecho» en $R E V L 89$, septiembre-octubre 1956, págs. 657-665. 
administrativa, según advierte Álvarez GendiN ${ }^{86}$. Por otra parte, la LJCA se orienta no sólo a garantizar la situación del particular, sino que también se dirige a obtener una resolución expresa debidamente fundada, cuyo deber no excluye la resolución presunta (art. 38.2). No obstante, el contexto político de la época franquista propicia la inexistencia de mecanismos efectivos para hacer realidad este deber. Ello es seguramente debido a la inexistente función democrática de la motivación del acto administrativo ${ }^{87}$. Por eso las garantías ${ }^{-d e l}$ particular se satisfacen con el acceso a la jurisdicción, pero no con la obtención de una resolución fundada en Derecho.

El carácter garantista del silencio administrativo en la LJCA conlleva incluso la vigencia de las disposiciones anteriores que hayan regulado la institución de forma más favorable. La mayoría de los autores ${ }^{88}$, salvo alguna excepción ${ }^{89}$, entendieron vigentes los supuestos de silencio positivo regulados por el RSCL y por el Reglamento del Ministerio de Trabajo, así como aquellos plazos más breves de silencio negativo como los previstos en el Reglamento del Ministerio de Gobernación. Con la nueva regulación el plazo para interponer el recurso contencioso-administrativo oscila entre los dos meses y un año, según se haya dictado un acto expreso o se haya producido el silencio administrativo. Esta distinción se justifica por cuanto «se acomoda perfectamente al nivel de formación y conocimiento de la gran mayoría de los administrados, a quienes no puede exigirse que obren como sólo sería posible hacerlo si la técnica del acto presunto, realizado por silencio administrativo, y los casos y plazos de éste fueran de dominio general». Entenderlo de otra forma «equivale a condenar a indefensión a la gran masa de administrados españoles y admitir que, para ellos, habrán de prevalecer casi siempre, por no interponer el recurso oportunamente, los actos conformes a Derecho realizados en virtud de la sutil figura del silencio administrativo». (Vid. la Exposición de Motivos de dicha Ley).

Si algo cabe objetar a la regulación del silencio administrativo negativo que hace la LJCA es que alarga significativamente el acceso del administrado a la jurisdicción con diversas medidas. Entre las mismas está el mantenimiento de

86 Vid. Sabino ÁlvAREZ GendiN, «El silencio administrativo en la nueva Ley de la jurisdicción contencioso-administrativa» en $B C N$ 155, 1957, pág. 653.

87 Este extremo ha sido puesto acertadamente de relieve por Marcos-Matías Fernando Pablo, La motivación del acto administrativo, Ed. Tecnos, Madrid, 1993, págs. 120-121.

88 Vid. Jesús GONZALEZ PÉREZ, «El silencio administrativo» en Revista iberoamericana de Derecho procesal 3, 1957, pág. 762; Fernando GARRIDO FALA, «El silencio administrativo en la nueva Ley de la jurisdicción contencioso-administrativa» en REVL.91, 1957, pág. 64.

89 Vid. José María BoQUERA OLIver, «Algunas dificultades de la actual regulación del silencio administrativo» en $R A P$ 30, 1959, pág. 89. Es más, llegaba incluso a afirmar que en la Administración local no existía ninguna posibilidad de silencio positivo ni de modificación de plazos. 
la denuncia de la mora en vía de petición en relación al silencio negativo, pese a que algunos autores habían señalado diversos inconvenientes ${ }^{90}$. Recordemos que la introducción de este mecanismo se produce en unas circunstancias muy diferentes y con una concepción muy distinta de la misma jurisdicción contencioso-administrativa. La justificación del mantenimiento de la denuncia de la mora se encuentra ahora en que es el sistema «más razonable, pues [...] viene a ser un recordatorio a la Administración, ante el cual procurará resolver dentro del nuevo plazo a fin de evitar un recurso ulterior si estima fundada la petición»" ${ }^{91}$. Es más, a diferencia de la legislación local donde el silencio en vía de petición se producía por el transcurso de tres meses, denuncia de la mora y un mes, con la LJCA este mes se alarga hasta tres meses. Además, en caso de producirse el silencio en vía de petición no abre directamente las puertas a la jurisdicción contencioso-administrativa sino al recurso de alzada, en caso de que éste procediera.

El año 1956 no es sólo importante por la gran reforma procesal de lo contencioso-administrativo, sino por iniciarse la denominada «reforma administrativa» ${ }^{92}$. Su principal promotor e impulsor fue el Catedrático de Derecho administrativo y entonces Secretario General Técnico de la Presidencia del Gobierno D. Laureano LOPEZ RODO ${ }^{93}$. Con la reforma se pretende recoger una serie de experiencias existentes en diversos países europeos dirigidas a modernizar la Administración pública. Especial relevancia tiene en este contexto Italia, donde la Comisión Forti elaboró diversos proyectos legislativos que aunque no llegaron a ser Ley tuvieron una influencia doctrinal decisiva ${ }^{94}$.

\footnotetext{
90 Así, el profesor Laureano LOPEZ RODó refiriéndose a la misma señala: «Complica el mecanismo del silencio administrativo, hace indeterminado su plazo (que puede oscilar según la Ley de Régimen local entre los cuatro y los trece meses y prolongarse sine die en los Reglamentos de Gobernación, Trabajo e Industria) y supone un debilitamiento del carácter automático del silencio al exigir la intervención del interesado en denunciar un hecho patente que a la Administración no es lícito olvidar: que tiene sin resolver una pretensión o reclamación». Vid. de este autor «Necesidad de una nueva regulación...», op. cit., pág. 660.
}

91 Vid. Jesús González PÉrez, «El silencio administrativo» ..., op. cit., pág. 127.

92 Según el profesor Laureano LOPEZ RODO: «El verdadero comienzo de la reforma administrativa en España tiene lugar en diciembre de 1956. En este momento se cré, como órgano específico para dicho propósito, la Secretaría General Técnica de la Presidencia del Gobierno. Su finalidad aparece claramente perfilada en el artículo primero del Decreto-ley de su creación: "[...] Será el órgano de estudio y documentación, asistencia técnica, coordinación y elaboración de planes de la Presidencia del Gobierno, especialmente en cuanto se refiera a la reforma y perfeccionamiento de la organización y de la actividad administrativa"». Vid. de este autor "La reforma administrativa en España» en DA enero 1958, págs. 7-8.

93 Este período es narrado por él mismo en sus Memorias, Ed. Plaza \& Janés, Cambio 16, Barcelona, 1990.

94 Así lo atestigua el importante trabajo del profesor Rafael ENTRENA CUESTA, «La reforma de la Administración pública en Italia» en $R A P 20$, mayo-agosto 1956, págs. 191-221. 
Entre los grandes logros de la reforma administrativa puede encontrarse la Ley de régimen jurídico de la Administración del Estado, cuyo Texto refundido es aprobado por Decreto de 26 de julio de 1957. Como ya notaron algunos de sus opositores: «Bajo la apariencia de una simple ley administrativa, se nos presenta hoy un proyecto que viene a alterar profundamente las bases del régimen» ${ }^{95}$. Siendo calificada en su defensa ante el Pleno de las Cortes españolas por el Catedrático de Derecho político Luis Sánchez Agesta como la «Carta Magna de los administrados» ${ }^{96}$. La Ley realiza una distribución de competencias entre los diversos órganos de la Administración, posibilitando la delegación de atribuciones en órganos inferiores. También debe destacarse la regulación general de las disposiciones y resoluciones administrativas, así como el régimen de responsabilidad de la Administración. Con estas medidas, tanto organizativas como de actividad, se persigue agilizar y modernizar la Administración pública, adaptándola al nuevo contexto económico y social. Se potencia, por tanto, el papel de los administrados en sus relaciones con la Administración, de forma que pueden dirigir instancias y peticiones a las autoridades y organismos en materia de su competencia. Éstos estarán obligados a resolver las instancias que se les dirijan por las personas directamente interesadas o declarar, en su caso, los motivos de no hacerlo (art. 39).

Durante este período, además de reformas legislativas, se promueve desde la Secretaría General Técnica de la Presidencia del Gobierno la I Semana de Estudios sobre la Reforma Administrativa, donde intervienen destacados Catedráticos de Derecho administrativo (así por ejemplo el profesor Manuel Ballbé Prunes) y representantes de los diversos departamentos ministeriales. Se intenta acabar en estos momentos con ciertas «costumbres administrativas» en las que no se concebía el silencio como una forma ordinaria de resolución del procedimiento. Así, uno de los intervinientes el Sr. Serra refiriéndose al silencio administrativo señaló que «nunca debe ser juzgado como indicio de pereza administrativa, pues, en muchos casos, dice, es, costumbre administrativa la redacción de un brevísimo informe a la autoridad que tiene que decidir, haciéndole ver la conveniencia de no dictar resolución alguna» ${ }^{97}$. El Sr. López Rodó replicó esta

95 Vid. la intervención en la primera sesión de la Comisión de Cortes que discutio el proyecto de ley, la intervención del Sr. Paulino Martínez Hermosilla. Citado por Laureano LOPEZ RODO, Memorias ..., op. cit., pág. 108.

96 Vid. Laureano LOPEZ RODర, Memorias ..., op. cit., pág. 109.

97 Esta «costumbre administrativa» había sido recogida normativamente por algunas Ordenanzas locales algunos años antes, por lo que no es de extrañar que en 1957 fuera defendida públicamente esta posición. Así, a título de ejemplo, cabe citar los arts. 2165 y 2166 de las Ordenanzas municipales de la Ciudad de Barcelona, aprobadas por Pleno de 29 de julio de 1947: «La Administración municipal sólo suspenderá la tramitación de un expediente, denegando tácitamente una solicitud o recurso en aplicación del silencio administrativo, por decisión expresa del Teniente de Alcalde Delegado o Jefe del Nego- 
posición señalando que el silencio administrativo «es un trato de favor al administrado para que no sea burlado en sus derechos, y puede decirse que su finalidad no es otra que la apertura violenta de la puerta de la jurisdicción contencioso-administrativa» ${ }^{98}$. Este incidente pone de relieve la inercia de ciertos planteamientos que, paradójicamente, han llegado hasta nuestros días.

En 1958 se producen determinados acontecimientos de gran interés. Así, aparece la revista Documentación administrativa como uno de los mecanismos creados para impulsar y difundir la reforma administrativa. En la misma publicarán prestigiosos autores con la intención de dotar instrumentos para mejorar la eficacia y el funcionamiento de las Administraciones públicas. Es bastante significativo que ya en los primeros números aparecieron diversos estudios sobre el silencio administrativo ${ }^{99}$. No obstante, es sobre todo a nivel legislativo donde se producen las novedades de mayor enjundia.

En efecto, a través de las denominadas Leyes fundamentales se consigue introducir a nivel «constitucional» determinadas garantías procesales. Es de destacar al respecto el «derecho a una justicia independiente» que proclamaba el principio IX de la Ley de 17 de mayo de 1958, de principios fundamentales del Movimiento Nacional. De tal forma que llega a decirse que «promulgados los principios del Movimiento Nacional, puede afirmarse que los españoles tienen reconocidas las garantías jurisdiccionales máximas en sus relaciones con la Administración» ${ }^{100}$. Más contundentes son las palabras del entonces Presidente del Tribunal Supremo, D. José CASTÁn ToBEÑAS, al afirmar que: «En la actualidad, resulta indudable que el Estado español es un auténtico Estado de

ciado respectivo y mediante diligencia extendida en él con sujeción a las reglas establecidas en los articulos siguientes». «Si la solicitud fuera manifiestamente improcedente por referirse a competencia extraña a la municipal por instarse en ella declaraciones sobre derecho o beneficios cuyo otorgamiento, modificación o extinción vengan prohibidos por preceptos de carácter general o local, o cuando los recursos no sean admisibles por defectos de forma o de fondo, el Jefe de Negociado suspenderá la tramitación ulterior del expediente, consignando la nota de "visto" bajo su firma y fecha. En los demás casos, el acuerdo de silenciar corresponde al Teniente de Alcalde Delegado, previo informe verbal del Jefe de Negociado sobre la razón que aconseje la suspensión del trámite o la desestimación del recurso, y lo consignará por escrito, en la forma señalada en el artículo anterior o por simple diligencia de "Dada cuenta" puesta por el Jefe informador con el $V .^{\circ} B .^{\circ}$ del Jefe de Sección".

98 Vid. Actas de la I Semana de Estudios sobre la Reforma Administrativa. Universidad Internacional Menéndez Pelayo, Palacio de la Magdalena, Santander, 19-26 de julio de 1957, Ed. Presidencia del Gobierno, Secretaría General Técnica, Madrid, 1958, pág. 105.

99 A título de ejemplo cabe citar a Jesús GONZÁLEZ PÉREZ, «El silencio administrativo en la nueva Ley de Procedimiento» en Documentación Administrativa 8-9, 1958, págs. 35-42.

100 Vid. «Los principios fundamentales del Movimiento Nacional y la Administración pública» en RAP 27, septiembre-diciembre 1958, pág. XXVII. Tales comentarios aparecen sin firma. 
LA EVOLUCIÓN HISTORICA DEL SILENCIO ADMINISTRATIVO: ..

Derecho», destacando el importante papel que tiene al respecto la jurisdicción contencioso-administrativa ${ }^{101}$.

Con todo, este importante nivel de garantías gestado desde las mismas entrañas del régimen (téngase en cuenta el formidable papel que jugó el Consejo de Estado y el Tribunal Supremo) no deben llevarnos a engaños sobre la inexistencia de un auténtico Estado de Derecho durante todo el franquismo ${ }^{102}$, pues el régimen carecía de otros elementos importantes que pudieran identificarlo con este tipo de Estado ${ }^{103}$. El Estado resultante de estos regímenes autoritarios se caracteriza, como es sabido, por la falta de garantía de los derechos de libertad y la ausencia de una auténtica separación de poderes ${ }^{104}$, pese a las proclamaciones rituarias que se formularán desde las más altas instancias del Estado, apoyándose en destacados juristas ${ }^{105}$ incluida la más alta magistratura ${ }^{106}$. Lo

101 Vid. de este autor Los principios filosófico-jurídicos y jurídicos politicos del Régimen Español, Madrid, 1963, púg. 73. Este trabajo es una separata de la 2." edición de la obra El nuevo Estado español. Entre los argumentos en los que venía a demostrar su afirmación cabe destacar que: «entre las tradicionales garantías técnico-jurídicas que sirven para asegurar el Estado de Derecho, ninguna tiene tanta importancia como la justicia llamada contencioso-administrativa, especialmente dentro de un sistema de tan pura esencia judicial como el que rige en España a virtud de novísimas leyes». Añadiendo en la nota a pie de página 175 que: «Las realizaciones del legislador español encaminadas a la afirmación y consolidación de un genuino Estado de Derecho culminan en la Ley reguladora de la jurisdicción contencioso-administrativa de 27 de diciembre de 1956, muy progresiva».

102 Algún autor ha llegado a sostener recientemente que: «[...] el Estado franquista, al menos el que yo conocí en la década de los sesenta, era un verdadero Estado de Derecho". Si bien matiza inmediatamente tal afirmación: «Es decir, un Estado en el cual, pese a su precaria legitimidad, los poderes públicos actuaban según normas preestablecidas y donde jueces y funcionarios nos tomábamos muy en serio ese genio expansivo del gobierno de las leyes en lugar del gobierno de los hombres». Vid. Miguel HeRrero Y RodRíGueZ de Miñón, Memorias de estío, Ed. Temas de Hoy, Madrid, 1993, pág. 22.

103 Vid. Elías Díaz, Estado de Derecho y sociedad democrática, Ed. Taurus Humanidades, 1992, octava reimpresión (la primera edición es de 1966).

104 El profesor Massimo Severo GianNINI advierte del riesgo que tiene la opinión que el Derecho administrativo es una consecuencia del Estado de Derecho. Así, señala que «la identificación del Estado de Derecho con el Estado que posee un Derecho administrativo sirve bastante bien para pasar de contrabando la tesis de que también los Estados fascistas fueron Estados de Derecho». Vid. de este autor Premisas..., op. cit., págs. 50-51.

105 Es conocida la polémica de Carl SCHMrtr con parte de otros juristas afectos al nacional-socialismo. Vid. Alessandro BARATTA, «El Estado de Derecho. Historia del concepto y problemática actual» en Sistema 17-18, abril 1977, especialmente págs. 18-20. Por otro lado, es conveniente recordar la tensión que hacia 1962-1964, enfrentó al régimen de Franco con la Comisión Internacional de Juristas, sita en Ginebra, como nos recuerda Ángel GARRORENA MORALES, El Estado español como Estado social y democrático de Derecho, Ed. Tecnos, Col. «Temas clave de la Constitución española», Madrid, 1990, pág. 158, nota 2.

106 Sobre el tema vid. Francisco José BASTDDA FREJEDO, Jueces y franquismo. El pensamiento político del Tribunal Supremo en la Dictadura, Ed. Ariel, Barcelona, 1986, pág. 120. Este autor cita diversa jurisprudencia del TS donde se proclama «la legalidad que debe presidir las actividades de la Administración y administrados en todo Estado de Derecho y dentro de él nos movemos». 
que sí debe reconocerse es que fue uno de los factores determinantes que posibilitarían ulteriormente el proceso de transición política hacia el actual y verdadero Estado de Derecho ${ }^{107}$.

Si bien los jueces constituyen para el régimen el puntal del «Estado de Derecho", cabe advertir la inexistencia de un auténtico Poder Judicial ${ }^{108}$. En efecto, la Administración de Justicia durante el régimen franquista se caracteriza «por su falta de independencia y de unidad jurisdiccional, dos caracteres esenciales del Estado de Derecho» 109. De esta forma, tras un aparente «tecnicismo», «apoliticidad» y «neutralidad» de los jueces ${ }^{110}$, el proceso de selección pasaba en los años ' 50 y hasta la finalización del régimen por una Escuela Judicial instituida como «un centro de adoctrinamiento político» " ${ }^{111}$. Asimismo, el Gobierno conservaba la designación de los puestos claves, encargados a su vez de seleccionar y promocionar a jueces y magistrados. Ello no implica desmerecer los numerosos esfuerzos individuales, realizados desde la judicatura, sino que éstos fueron sobre todo el resultado de una toma de posición individual y no el resultado de un marco jurídico establecido ${ }^{112}$.

Otro de los grandes acontecimientos del año $1958 \mathrm{es,} \mathrm{sin} \mathrm{lugar} \mathrm{a} \mathrm{dudas,} \mathrm{la}$ promulgación el 17 de julio de la Ley de procedimiento administrativo ${ }^{113}$. Pese a

107 El mismo Miguel HeRreRo y RODRÍGUeZ DE MiN̄ón advierte que: «Si la transición política de los setenta no hubiera sido posible sin la estabilización económica de 1959 y el ulterior desarrollo, tampoco lo hubiera sido sin la creación de un moderno sistema jurídico-administrativo en los mismos años». Vid. de este autor Memorias..., op. cit., pág. 24.

108 Cuando posteriormente el Constituyente de 1978 adopto en la rúbrica del Título VI la expresión «Poder Judicial» en vez de "Administración de Justicia» lo hizo de forma plenamente consciente como reacción a la situación existente en la época que ahora tratamos. Vid. Francisco ToMÁs Y VALIENTE, «Poder Judicial y Tribunal Constitucional» en PJ 2." época, núm. especial XI, págs. 13-30.

109 Vid. Antonio TORRES DEL MORAL, Constitucionalismo histórico españọl, 4.` edición, Ed. Átomo, Madrid, 1991, pág. 234.

110 Para Sabino Álvarez-Gendín y Blanco, «El Poder Judicial debe ser independiente del ejecutivo en los siguientes aspectos que vamos a estudiar, y que postulamos como principios y lo es de iure en el segundo y en el tercero de los mismos: I, en cuanto a la designación de sus miembros; II, en cuanto a su ejercicio; y IIl en cuanto a su régimen disciplinario y a su responsabilidad civil». Vid. «El Estado de Derecho y el Poder Judicial independiente» en RAP 31, enero-abril 1960, págs. 13-14, también en La independencia del Poder Judicial. La especialización de los Tribunales contencioso-administrativos, Ed. IEP, Madrid, 1966, pág. 72.

111 Vid. Juan CANo Bueso, La política judicial del régimen de Franco, Ed. Ministerio de Justicia, Madrid, 1985, pág. 182.

112 Vid. Francisco TOMÁs Y VALIENTE, «Poder judicial...», op. cit., págs. 15-16.

113 Vid. el discurso de LÓPEZ RODó ante el Pleno de las Cortes en defensa de la Ley de procedimiento administrativo, el 15 de julio de 1958, titulado «Del Estado liberal al Estado social de Derecho», publicado en el libro de este autor Política y desarrollo, 2." edición, Ed. Aguilar, Madrid, 1971. En las págs. 143-144 
su nombre no se limita a regular aspectos meramente procedimentales «sino también los principios generales de organización y actuación, el régimen de los actos administrativos y la situación de los interesados en el expediente». Constituye, por tanto, «un verdadero Código administrativo», inspirado en las siguientes ideas capitales:

«a) Unidad y flexibilidad del procedimiento. b) Simplificación de trámites e incremento de la productividad. c) Colaboración de los administrados, y d) Reducción del número de disposiciones reglamentarias ${ }^{114}{ }$.

No obstante, cabe decir que esta Ley añade pocas novedades al régimen del silencio administrativo, en relación al art. 38 de la LJCA. La innovación que podía haber resultado más espectacular quedó frustrada en vía de proyecto, dejándose mera constancia de ello en la redacción de la Exposición de Motivos ${ }^{115}$. Por tanto, el art. 99 del Proyecto de Ley de procedimiento administrativo establecía de forma pionera una generalización del silencio positivo en el ámbito de las autorizaciones regladas ${ }^{116}$. No obstante, en el Dictamen de la Ponencia, elaborado por la Comisión de Leyes Fundamentales y Presidencia del Gobierno ${ }^{117}$, este precepto sufre una variación fundamental, eliminándose su aplica-

señala que: «Para el cabal conocimiento de este Proyecto de Ley es preciso, pues, encuadrarlo dentro del plan de conjunto de la reforma administrativa que se está llevando en España. Y digo reforma administrativa empleando una expresión universalmente consagrada para designar un fenómeno común a numerosos países. Yo preferiría, desde luego, hablar de modernización y perfeccionamiento de la Administracións.

114 Vid. el Boletín Oficial de las Cortes Españolas 601, de 15 de julio de 1958, pág. 12.445, correspondiente a la defensa del entonces Proyecto por el Procurador en Cortes D. Laureano LópEz Rodo.

115 Según la citada Exposición de Motivos: «[...] se prevé el silencio positivo, sin denuncia de la mora, aparte de en los casos prevenidos en normas especiales, cuando se trate de autorizaciones previas al ejercicio de derechos subjetivos cuyo otorgamiento no fuese discrecional, o de autorizaciones o aprobaciones en que se concrete el ejercicio de las funciones de fiscalización de los órganos superiores sobre los inferiores».

116 «Art. 99. 1. El silencio se entenderá positivo, sin denuncia de la mora, cuando se formulare alguna petición ante la Administración y ésta no notificare su decisión en el plazo de dos meses, en los casos siguientes:

a) Autorizaciones previas al ejercicio de derechos subjetivos, salvo si estuviere dispuesto lo contrario o fuese discrecional su otorgamiento.

b) Autorizaciones o aprobaciones que deben otorgarse por los órganos de la Administración en ejercicio de sus funciones de fiscalización y tutela sobre los órganos inferiores.

c) En los demás casos prevenidos por normas especiales.

2. El plazo a que se refiere el parrafo anterior será inferior si asf lo previenen las normas especiales aplicables.»

117 Formaban parte de la misma los Sres. D. José Ignacio Escobar Kirkpatrick, D. Laureano López Rod6, D. Alberto Martín Artajo, D. Luis Rodriguez de Miguel, D. Segismundo Royo-Villanova. Este último se había pronunciado en diversos artículos doctrinales sobre los peligros que implicaba la técnica del silencio positivo en relación al interés público. 
ción directa a las autorizaciones regladas, y quedando con la redacción definitiva de lo que sería el art. 95 de la LPA.

La unidad del procedimiento y la reducción de disposiciones reglamentarias, dos de los pilares de la Ley, llevaron a la derogación de los Reglamentos dictados para la ejecución de la Ley de 19 de octubre de 1889, sin realizar ningún tipo de distinción. Se acabó, por tanto, con la subsistencia de algunos reglamentos considerados más garantistas para el ciudadano y cuya vigencia había sido mantenida expresamente por la LJCA. Así, por ejemplo, quedaba derogado el Reglamento del Ministerio de Trabajo que establecía la regla general del silencio positivo en el ámbito de su Departamento ${ }^{118}$. En cambio, a pesar de ciertas vacilaciones iniciales ${ }^{119}$, se consideró vigente la regulación del RSCL que establecía los efectos estimatorios del silencio en el ámbito de las licencias municipales. Los argumentos que justificaron la supervivencia de este reglamento se fundamentaban en que estaba desarrollando la Ley de régimen local entonces vigente. Por ello, no podía considerarse en sentido estricto un reglamento de ejecución de la Ley de procedimiento de 1889.

La LPA renuncia a regular con carácter general el silencio positivo en las relaciones particular-Administración, remitiéndose a la legislación sectorial. Este renuncia será cubierta por la subsistencia del RSCL, si bien queda limitada al ámbito de las licencias municipales. En cambio, la LPA establece una regulación general en el ámbito de las relaciones interorgánicas. No se prevé, sin embargo, qué sucede con las relaciones intersubjetivas o entre diversas Administraciones públicas. La razón de ello quizás pueda encontrarse en que aún no se había producido el gran desarrollo de la Administración institucional, cuya regulación general será aprobada a finales de año (Ley de 26 de diciembre de 1958, de entidades estatales autónomas). Respecto a las relaciones de las entidades locales con la Administración del Estado ya existían amplios supuestos en la legislación local desde los Estatutos de Calvo Sotelo y que en 1958 recogía la legislación local entonces vigente. Cabe añadir, además, la inexistencia de una autonomía local, que limitara en muchos de los supuestos las relaciones de tutela a controles de mera legalidad.

También parece sorprendente la dispensa de la denuncia de la mora en los casos de silencio positivo, en claro contraste con la regulación efectuada el año anterior por el RSCL. La existencia de un interés público a proteger parece que requería determinados mecanismos formales, como la denuncia de la mora, que atenuaran el automatismo del silencio. Esta deficiencia legislativa es cubierta por la jurisprudencia años más tarde, dejando prácticamente vacío de

118 Así lo ratificó con posterioridad la jurisprudencia en STS de 30 de mayo de 1961 (ref. Ar. 2428).

119 Vid. la STS de 2 de mayo de 1960. 
LA EVOLUCIÓN HISTÓRICA DEL SILENCIO ADMINISTRATIVO: ..

contenido al art. 95 de la LPA que sólo es visto como un mecanismo de remisión a la legislación sectorial y como cláusula de interpretación restrictiva del silencio positivo. Debe advertirse que el objetivo de la reforma no era solamente realizar nuevas leyes, sino introducir mecanismos que permitieran mejorar y perfeccionar la actividad y la organización administrativa ${ }^{120}$.

Tal planteamiento que fue plenamente asumido por el régimen ${ }^{121}$, quedó sin embargo, en muchos de sus aspectos en el puro plano teórico. Un ejemplo de ello puede encontrarse en una norma innovadora como la del art. 39 de la LPA. Con este precepto se pretendía que en las autorizaciones que hubieran de referirse a un solo asunto y objeto y correspondiera intervenir a varios departamentos o centros directivos, se instruyera un solo expediente y se dictara una resolución única ${ }^{122}$. Si bien esta norma debió «tener desde el momento mismo de la entrada en vigor de la Ley, plena aplicación, es lo cierto que [...] su eficacia práctica se ha ido abriendo paso trabajosamente, y cuando lo ha hecho, ha sido casi siempre por la vía tan poco deseable del planteamiento de conflictos y tensiones entre los órganos por él afectados» ${ }^{123}$.

La reforma administrativa consigue, por tanto, importantes resultados pero también quedan en el papel muchos de ellos. Bajo la bandera de reforma se alinearon, por lo demás, posiciones muy simplistas «que querían vendernos su panacea prescindiendo de las reglas jurídicas más consagradas en aras de una

120 Así lo atestiguan las siguientes palabras: «La tarea de poner al día la Administración pública no es simplemente un asunto jurídico. Consiste, ante todo, en incrementar su eficacia. El público demanda, justamente, la desaparición de la pesadilla de las dilaciones y los retrasos. El ciudadano nos recuerda que su tiempo es valioso y desea ponerse en contacto con la Administración sin dificultades ni trabas inútiles. Naturalmente, espera ser atendido con rapidez y eficacia, con un mínimo de papeles y sin formalidades innecesarias». Vid. Laureano LÓPEZ RODO, «La reforma...», op. cit., pág. 8.

121 Es bastante sintomático el mensaje de fin de año de 1960 pronunciado por el entonces Jefe del Estado, donde se señala que: «La Administración pública tiene que incorporarse a las modernas técnicas orgánicas y funcionales. El viejo concepto de la Administración obstaculizadora y retardataria por su excesivo burocratismo tiene que ser sustituido por un auténtico sentido empresarial y de servicio. Por estos derroteros va discurriendo nuestra reforma administrativa, cuyo avance prosigue día a día.» Citado por Laureano LÓPEZ RODO, Política..., op. cit., pág. 40.

122 En la actualidad debe entenderse que dicha norma continúa en vigor, si bien con carácter reglamentario, de acuerdo con la disposición derogatoria única apartado tercero de la Ley 6/1997, de 14 de abril, de organización y funcionamiento de la Administración General del Estado (LOFAGE).

123 Vid. Luis de la MORENA Y DE LA MORENA, «Una norma innovadora: la del artículo 39 de la Ley de procedimiento administrativo» en DA 76, 1964, pág. 27. También vid. Alejandro NiETo Garcta, La organización del desgobierno. Ariel, Barcelona, 1984, pág. 64, que al referirse a esta norma advierte que: «tal precepto ha resultado inútil desde el momento en que ningún ministerio acepta su subordinación. Con la consecuencia de que un mismo asunto es tramitado en expedientes simultáneos y paralelos; llegándose al caso, como sucede en las autorizaciones de la zona marítimo-terrestre, en que intervienen nada menos que diecisiete organismos administrativos, cada uno de los cuales dicta su propia resolución que, por supuesto, puede ser contraria a las demás». 
eficacia cuya avallasadora prioridad no acababa de verse» ${ }^{124}$. Esta situación fue satirizada con agudeza e ingenio por GonZÁlEZ PÉREZ en una célebre conferencia pronunciada en Peñíscola sobre la reforma administrativa local ${ }^{125}$.

La remisión del art. 95 de la LPA a una disposición expresa propiciará que se dicten algunas normas donde se recoja la institución del silencio administrativo positivo, si bien las mismas no son muy abundantes. Entre las mismas cabe destacar, sin duda, al Reglamento de actividades molestas, insalubres, nocivas y peligrosas (RAC), aprobado por Decreto 2414/1961, de 30 de noviembre (BOE 292, de 7 de diciembre de 1961). Este reglamento, como ya había realizado en 1955 el RSCL, introduce la denuncia de la mora en casos de silencio positivo. Ello pese a que ahora el art. 95 de la LPA dispensaba expresamente su aplicación. La razón por la que se introduce este mecanismo obedece, sin duda, a la propia particularidad de estos procedimientos en los que intervienen sucesivamente dos Administraciones públicas.

La doctrina criticó que con estos reglamentos se introducía «una denuncia de la mora diferente de lo establecido en la Ley de procedimiento" ${ }^{126}$. Tales diferencias consistían en que la mora había de denunciarse simultáneamente ante el Ayuntamiento y la Comisión Provincial de Servicios Técnicos. Esta Comisión que originariamente nace en la órbita de la Administración provincial con funciones de asistencia técnica a municipios con pequeño número de habitantes, pasó a «convertirse en un organismo burocrático y estatal, tanto por su naturaleza como por su composición y por sus funciones, que se inmiscuye de forma gravísima» en la Administración local ${ }^{127}$. La trascendencia que adquirieron estos órganos en el procedimiento de otorgamiento de licencias de actividades clasificadas justificaban que se les diera conocimiento de la inactividad municipal a través del mecanismo de la denuncia de la mora.

La jurisprudencia entendió que la denuncia de la mora prevista por el RSCL y por el RAC no constituía un recurso de alzada encubierto, según había denunciado unos años antes destacados autores (ALBI CHOLBI). En realidad se procedía a una subrogación frente a una inactividad de la Administración municipal para evitar un grave perjuicio al interés público. Se argumenta que en

124 Vid. Lorenzo MARTÍN-RETORTLLO BAQUER, «Proemio» en AA.VV.: La protección juridica del ciudadano (Procedimiento administrativo y garantía jurisdiccional). Estudios en homenaje al Profesor Jesús Gónzalez Pérez, vol. I, pág. 23.

125 Vid. de este autor: «La reforma administrativa en el régimen local» en Problemas políticos de la vida local, Ed. Instituto de Estudios Políticos, Madrid, 1961, págs. 129-153.

126 Vid. José Luis GONZÁlez-BERENGUER URRUTIA, «La reforma del reglamento de actividades molestas, insalubres, incómodas y peligrosas» en RAP 45, septiembre-diciembre 1964, pág. 373.

Vid. Alejandro Nieto García, «La organización local...», op. cit., pág. 148. 
LA EVOLUCIÓN HISTÓRICA DEL SILENCIO ADMINISTRATIVO: ..

estos casos no hay un acto que deba revisarse a través del mecanismo de los recursos administrativos, sino que se parte «de la premisa de la inexistencia del acto administrativo, y se busca el acicate del órgano superior para que detenga las aspiraciones del particular o se perfeccione con su silencio en un tiempo dado el acto municipal presunto que está en vía de génesis» ${ }^{128}$.

En definitiva, con la intervención de la Comisión y con la denuncia de la mora, se consiguen dos objetivos importantes: se dificulta la consecución del silencio positivo que es visto con reticencia y desconfianza por la mayoria de los especialistas, al mismo tiempo que se introducen determinadas limitaciones a la ficticia autonomía municipal.

Durante los años 50-60 se producen, asimismo, diversos fenómenos de gran trascendencia. Así, tiene lugar un creciente éxodo de población del campo a las grandes ciudades lo que provoca una mayor necesidad de suelo urbano para poder edificar nuevas viviendas. El proceso de desarrollo urbano se caracterizó «por la densificación congestiva de los cascos centrales de las ciudades, el desorden de la periferia, la indisciplina urbanística y los precios crecientes e injustificados del suelo aptos para el crecimiento de las ciudades" ${ }^{129}$. Se produjo en aquellos momentos un fuerte fenómeno de especulación del suelo, que propicia un notable incremento de actuaciones que implican la defraudación de la legalidad urbanística ${ }^{130}$. Situación que se ve favorecida en cierta forma por la actitud tolerante de algunas de las Administraciones públicas ${ }^{131}$.

\footnotetext{
128 Este último argumento de la «inexistencia» del acto que esgrime la STS de 12 de diciembre de 1968 no es muy convincente, pues podría replicarse que la petición del Ayuntamiento ha sido desestimada por silencio administrativo y que ante ello se interpone un recurso administrativo ante la Comisión que en caso de no resolverse generaría un supuesto de silencio positivo, de forma similar a como en la actualidad prevé el art. 43.2.c) de la LRJPAC.

129 De esta forma lo describiría años más tarde la Exposición de Motivos de la Ley 19/1975, de 2 de mayo, de reforma de la Ley sobre régimen de suelo y ordenación urbana.

130 La STS de 7 de noviembre de 1972 (ref. Ar. 4699): «[...] ya por el constante acceso que sufren de los intereses contrapuestos que tienden a incrementar los volúmenes de edificación, ya como consecuencia de la atonía administrativa, o de la imposibilidad material de signo económico de ejecutar el Plan en tiempo, instrumentando al efecto un severo control y rigurosas formalidades para la alteración de los espacios libres proyectados, y sancionando radicalmente y sin paliativos la mutación de destino cooperada al margen de la Ley de 2 de diciembre de 1963 [...]". Asimismo, la STS de 28 de octubre de 1978 (ref. Ar. 3960) señala que «la aplicación indiscriminada del silencio positivo puede resultar en ocasiones sumamente peligrosa [...] por lo que la jurisprudencia no ha tenido más remedio que hacerle frente, con el fin de impedir la consumación de situaciones notoriamente injustas y contrarias a Derecho [...] razón también por la que en el nuevo texto de la Ley del Suelo de 9 de abril de 1976 se suprime de raíz la aplicación de este tipo de silencio, cuando ello implicara contradicción con las prescripciones de esta Ley, de los Planes, Proyectos, Programas y, en su caso, de las Normas Complementarias y Subsidiarias del Planeamiento".
}

131 Según la STS de 24 de noviembre de 1978 (ref. Ar. 4311): «donde no ha existido más que una simple pasividad, de la que a veces no es ajeno cierto tipo de picaresca burocrática». 
Este motivo parece ser el desencadenante de una fulminante reacción jurisprudencial que viene a minimizar la escasa virtualidad que en alguna ocasión haya podido tener el silencio positivo. Según esta versión se quiso evitar, por tanto, que a través de la técnica del silencio positivo llegaran a consolidarse situaciones contrarias al ordenamiento urbanístico. Para ello, aunque el particular hubiera presentado su solicitud y hubiera transcurrido el tiempo legalmente establecido, no podía decirse que se había producido el silencio positivo si la solicitud era contraria a la legalidad urbanística. Con esta interpretación se primó el elemento legalidad frente al de seguridad jurídica. De esta forma quedó desvirtuado el posible carácter favorable que el silencio positivo pudiera tener para el interesado, pues ni le permitía acceder a la jurisdicción ni le consolidaba en una situación, aunque hubiera transcurrido el tiempo legalmente previsto.

En realidad, si bien parece cierto que el detonante de esta reacción jurisprudencial puede encontrarse en el afán de prevenir la consolidación de ilegalidades urbanísticas, cabe también poner de relieve que en mayor medida es el resultado de una larga desconfianza doctrinal mantenida frente al silencio positivo, ya iniciada por Segismundo Royo-VILlanova y que ahora tiene su máxima culminación. No existen, por lo demás, estudios definitivos que demuestren que a través el silencio positivo se consolidaran numerosas actuaciones contrarias a la legalidad urbanística. Las sentencias que proclaman el carácter automático del silencio, prescindiendo de la legalidad de la solicitud, son ciertamente escasas. En realidad, el urbanismo incontrolado se produce no tanto como consecuencia de la inactividad en la resolución de los procedimientos de licencias, sino fundamentalmente por la inactividad en el ejercicio de las formidables potestades que la Ley del suelo otorgaba a la Administración para la protección de la legalidad urbanística (suspensión de licencias, ejercicio de la potestad sancionadora, imposición y ejercicio de obras de derribo, etc.).

Con todo la primacía del elemento legalidad frente a la seguridad jurídica en la interpretación del silencio positivo que introduce decididamente la jurisprudencia, será positivizada por la Ley 19/1975, de 2 de mayo, del suelo, y el Texto refundido de 9 de abril de 1976, al establecer que:

«En ningún caso se entenderán adquiridas por silencio administrativo facultades en contra de las prescripciones de esta Ley, de los Planes, de los Proyectos, Programas y, en su caso, de las Normas Complementarias y Subsidiarias del Planeamiento».

Esta reacción frente al silencio positivo es por lo demás perfectamente lógica y coherente con el sistema, pues la legislación sectorial se caracterizará por un fuerte componente autoritario que focalizará su atención en los controles 
LA EVOLUCIÓN HISTÓRICA DEL SILENCIO ADMINISTRATIVO: ..

previos, descuidando la sucesiva actividad de los interesados ${ }^{132}$. Parece como si el objetivo prioritario de las autorizaciones, como técnica de intervención administrativa, reside más en ejercer la autoridad y limitar la «libertad» existente que en perseguir el interés general.

Es sintomático este componente autoritario ex ante en sectores como industria, sistema bancario y crediticio, comercio, agricultura, etc. El predominio de autorizaciones con fuerte componente discrecional llevará a la doctrina a replantearse las mismas bases del concepto clásico de autorización. Será posteriormente con los sucesivos procesos liberalizadores que se irá desplazando el eje del control administrativo hacia la actividad del particular realizada ex post al otorgamiento del título administrativo ${ }^{133}$.

En definitiva, si las grandes leyes de los años 50 crearon un marco jurídico de gran perfección técnica dentro de un Estado autoritario, que centró su atención en potenciar las funciones de los Jueces y Tribunales, este nivel no se mantuvo con la mayoría de la legislación sectorial, incapaz en su mayoría de dotar a la Administración de instrumentos efectivos para agilizar su actuación y con ella la de la sociedad española de la época. Estas disfuncionalidades pasarían, sin embargo, bastante desapercibidas debido al auge económico de los años 60. Será más tarde, ya en plena transición a la democracia, cuando se evidenciaría esta situación como consecuencia de la crisis económica suscitada por la subida de los precios del petróleo.

\section{EL SILENCIO ADMINISTRATIVO EN LA TRANSICIÓN ESPAÑOLA Y LA INCORPORACIÓN A LA EUROPA COMUNITARIA: DE UN MECANISMO BÁSICAMENTE PROCESAL HACIA LAS NUEVAS TENDENCIAS DE SIMPLIFICACIÓN ADMINISTRATIVA}

Con la muerte del General Franco y el acceso al trono del Rey Juan Carlos I se inician los importantes cambios políticos que desembocarían finalmente en un auténtico Estado de Derecho con la Constitución de $1978^{134}$. La peculiar

\footnotetext{
132 Es mérito de la profesora Elisenda MALARET I GaRcía el destacar cómo en este período la regla será el control preventivo de la actividad de los particulares, sin ninguna consideración a las finalidades o objetivos de la acción y «paradojicamente a menudo sin control posterion». Vid. de esta autora «Le Droit administratif espagnol entre l'ordre juridique national...», op. cit., pág. 109.

133 Un dato significativo es la escasa bibliografía sobre las poderes de investigación e inspección existente respecto a nuestro ordenamiento jurídico.

134 Si bien es cierto la existencia de ciertos intentos aperturistas, sobre todo a raíz del asesinato del General y Presidente del Gobierno Carrero Blanco, no será hasta la decisión del Rey de forzar la dimisión
} 
evolución del Estado franquista posibilita esta tránsito pacífico hacia un sistema democrático. Evolución que se gesta desde el mismo aparato del Estado y sin romper con la legalidad precedente, a través de la Ley para la reforma política de 4 de enero de 1977, diseñada por Torcuato Fernández-Miranda (la denominada 8. Ley fundamental). El cambio político no supone, por tanto, rescindir en bloque de la legalidad anterior sino que procura integrarla en un nuevo ordenamiento constitucional, conforme a las nuevas exigencias de la sociedad española. Es por ello que la mayor parte del ordenamiento jurídico-administrativo permanecerá en vigor, si bien la nueva Constitución eliminará los aspectos contradictorios con el nuevo régimen de derechos y libertades. La ausencia de un marco legal actualizado, suplido por un conjunto de normas en su mayoría preconstitucionales, condicionará el estudio del Derecho administrativo, centrado más en temas de garantías que en el estudio de la organización y eficacia administrativa ${ }^{135}$. El nuevo régimen político se construirá sobre la base de una Administración pública fuertemente centralizada, que mantendrá intacta su base funcionarial ${ }^{136}$, si bien se abrirá al fenómeno de profunda transformación con la construcción del Estado autonómico y la nueva dimensión constitucional de los entes locales. Se eliminan, por tanto, los signos más notoriamente franquistas de las Administraciones públicas ${ }^{137}$ pero las instituciones más importantes del Estado autoritario pasan intactas al sistema democrático.

La transición política coincide cronológicamente con un período de grave crisis económica a nivel internacional, surgida en el sector energético por la subida de los precios del petróleo. En el caso español esta situación se ve agravada por la política económica de los sucesivos gobiernos implicados, que parecen desconocer la crisis para evitar la impopularidad y resistencia social que hubieran dificultado el cambio de régimen ${ }^{138}$.

de Arias Navarro, el 1 de julio de 1976, cuando se «abre objetivamente la transición a la democracia». En este sentido vid. Raúl Morodo, La transición política, Ed. Tecnos, Col. «Temas clave de la Constitución española», Madrid, 1985, pág. 101. Ello no significa desconocer la existencia de diversos acontecimientos políticos anteriores que posibilitaron que ello fuera así.

135 Vid. Luciano PaRejo Alfonso, Eficacia y Administración. Tres estudios, Ed. INAP y BOE, Madrid, 1995, pág. 20.

136 «[...] el aparato político que impulsa estas reformas, tanto a nivel constitucional como legislativo o ejecutivo, ha de contar para su realización, con el propio aparato administrativo del período de la dictadura franquista. No se produce, así, en esta transición, ningún tipo de depuración ni en la Policía, ni en el Ejército, ni en la Magistratura, ni en los Altos Cuerpos burocráticos vinculados más estrechamente al poder franquista». Vid. Luis ORTEGA ÁlvAREZ, «El Estado y la reforma de la Administración» en José Félix Tezanos; Ramón Cotarelo; Andrés de Blas (eds.), La transición política española, Ed. Sistema, Madrid, 1989, pág. 680.

137 Vid. Joan Prats I CATALA, «Administración pública y transición democrática» en Pensamiento iberoamericano Sb, enero-junio 1984, pág. 450.

Vid. Joan Prats I CatalA, «Administración pública y transición...», op. cit., pág. 453. 
LA EVOLUCIÓN HISTÓRICA DEL SILENCIO ADMINISTRATIVO: ..

Las líneas maestras del nuevo Estado son fruto de decisiones y acuerdos previos a la propia Constitución de 1978, conformando una realidad que recogería posteriormente nuestro Texto constitucional ${ }^{139}$. Singular importancia en este contexto son los denominados Pactos de la Moncloa (8-27 de octubre de 1977), en los que los diversos partidos políticos, con representación parlamentaria, de acuerdo con el Presidente del Gobierno (Adolfo Suárez) y otros miembros del mismo, sientan las bases de un consenso sobre diversas materias (saneamiento y reforma de la economía y actuación jurídica y política). La exigencia de garantizar determinados derechos y libertades (libertad de expresión, reunión y asociación, garantías contra las sanciones de orden público) provoca la adopción de importantes medidas jurídicas. En este sentido, desaparecen los controles previos de corte autorizatorio para el ejercicio de estos derechos, sustituyéndose por meras comunicaciones previas. Se produjo, como observó SA. LAS HERNÁNDEZ ${ }^{140}$, una desadministrativización de ciertos derechos y la correlativa intervención casi exclusiva de los Tribunales. Se articula asimismo un procedimiento preferente y sumario para la protección de los derechos fundamentales y libertades públicas, a través de la Ley 62/1978, de 26 de diciembre $^{141}$. Con esta norma se elimina la denuncia de la mora para estos procedimientos en casos de silencio negativo, posibilitándose el acceso directo a los tribunales a los veinte días de la solicitud del interesado. En estos momentos el silencio administrativo aparece entre las diversas medidas adoptadas para el «establecimiento de un proceso judicial rápido para la tutela del ejercicio» de estos derechos ${ }^{142}$.

Estos importantes precedentes desembocaron en la elaboración de la Constitución de 1978, bajo cuya batuta se abriría un nuevo camino en la historia del Estado español. Entre las preocupaciones de los Constituyentes adquiere un papel relevante la Administración pública. Sin duda, ello fue así por la necesidad de consagrar definitivamente los esfuerzos iniciados por la Generación de la $R A P$ para sujetar la actividad administrativa a la legalidad y al

139 Vid. Manuel ARAGÓN ReYeS, "Constitución y Estado de Derecho» en España: un presente para el futuro, vol. II, (Las instituciones), Ed. Instituto de Estudios Económicos, Madrid, 1984, pág. 80.

140 Vid. «Protección judicial ordinaria y recurso de amparo» en REDA 27, 1980, pág. 553. Tambiên publicado en Tribunal Constitucional, vol. III, Madrid, 1980.

141 Sobre esta Ley vid. por todos Javier SALAS HERnANDEZ; Joaquín TORNOS MAS, «Comentarios a la Ley de protección jurisdiccional de los derechos fundamentales de la personas» en RAP 93, septiembrediciembre 1980, págs. 29 y ss., más recientemente Marc CARRILL, La tutela de los derechos fundamentales por los tribunales ordinarios, Ed. BOE y Centro de Estudios Constitucionales, Madrid, 1995.

142 Vid. de esta forma el Acuerdo sobre el programa de actuación jurídica y política, aprobado el 27 de octubre de 1977 en el punto 6. del derecho de reunión. Vid. Los Pactos de la Moncloa. Texto completo del acuerdo económico y del acuerdo político, Ed. Secretaría General Técnica, Presidencia del Gobierno, Madrid, 1977. 
Derecho, afirmando plenamente la existencia de un Estado de Derecho. Testimonio de ello son los diversos preceptos que a la Administración dedica, como es sabido, nuestro Texto Fundamental.

El pleno control judicial a que se sometía la Administración pública, asegurado por el juego de los arts. 24 y 106, planteó singularmente el tema de la inactividad administrativa. En este sentido el Grupo Socialista formuló una enmienda al art. 104 del Anteproyecto de Constitución (en la actualidad se corresponde con el art. 106 de la CE) donde se establecía que los Tribunales «suplen la omisión de la actividad de la Administración cuando tal actividad sea obligada» ${ }^{143}$. La alternativa propuesta representaba como advirtió la doctrina una clara superioridad técnica frente al texto que acabó imponiéndose. Tal superioridad se concretaba en un mandato al juez para sustituir a la Administración en casos de inactividad cuando ésta tuviera la obligación de actuar ${ }^{144}$. La originalidad de la propuesta residía fundamentalmente en esta posibilidad de sustitución y no, en cambio, respecto a la superación de la doctrina del acto previo que ya incluía el texto definitivamente aprobado ${ }^{145}$. Las razones por las que prosperó la enmienda quizás fueron debidas a un exceso de celo o prudencia de la mayoría que aprobó la redacción definitiva del precepto. Tal vez se pensó que a través de esta consagración expresa del control de la inconstitucionalización se llevarían hasta las últimas consecuencias los derechos sociales que implantó entonces la Constitución ${ }^{146}$. De esta forma es probable que se quisiera evitar una excesiva rigidez de una norma de tal envergadura. A ello

143 Este tema fue objeto de un estudio específico de Luciano PAREJO ALFONSO, «La garantía jurisdiccional frente a la actividad administrativa: a propósito de los artículos 24 y 104 del Anteproyecto de Constitución» en RAP 84, septiembre-diciembre 1977, número homenaje a Eduardo García de Enterría, págs. 569-588.

144 El que los Tribunales suplan la inactividad administrativa adquiere un significado distinto a la sustitución judicial de la actividad discrecional de la Administración, tema objeto de amplio debate en nuestra doctrina, según veremos ulteriormente.

145 El profesor Luciano PAREJO ALFONSO se mostró muy crítico respecto a la redacción que acabo imponiéndose en al actual art. $106 \mathrm{CE}$. Vid. de este autor «La garantía jurisdiccional...», op. cit., págs. 574-575. Con todo, la posterior interpretación doctrinal y jurisprudencial del art. $24 \mathrm{CE}$ ha venido en gran parte a suplir las posibles objeciones entonces formuladas al art. 106.

146 En este sentido algún autor ha señalado: «Basta preguntarse por la suerte práctica que correría un recurso contencioso-administrativo en el que se solicitase la condena de la Administración a procurar «una vivienda digna y adecuada» a un recurrente que careciese de ella. Quizás fuese ésta la consideración realista que impidio que prosperase la enmienda, a pesar de que la doctrina administrativa nos ha mostrado en ocasiones la necesidad de disponer de instrumentos de lucha contra la pasividad administrativa, y de que hoy día es viable la acción declarativa contra la Administración al amparo de los arts. 28.2, 42 y 84.b de la Ley Jurisdiccional». Vid. Fernando GARRDO FALLA, «La posición constitucional de la Administración públicas en Femando GarRIDO FALLA; Mariano BaENA DEL ALCÁzAR; Rafael EN. TRENA Cuesta, La Administración en la Constitución. Ed. Centro de Estudios Constitucionales, Madrid, 1980, págs. 24-25. 
debe añadirse el carácter eminentemente técnico de la enmienda, motivo por el cual no debió constituir uno de los puntos que suscitara una defensa innegociable por los proponentes, todo ello dentro del marco del consenso constitucional. En cualquier caso, el hecho que no prosperara la enmienda no impedía que posteriormente volviera a plantearse la cuestión en la tramitación de una norma de rango superior, tal como realmente sucedió, según veremos posteriormente.

Los primeros gobiernos de la democracia, a la sazón de la UCD, pretendieron llevar a cabo un programa de reformas administrativas, en gran parte derivado de los Pactos de la Moncloa a los que nos hemos referido anteriormente. No obstante, tal programa quedó en gran parte incumplido ${ }^{147}$, por razones fundamentalmente políticas: «tras las elecciones de marzo de 1979, que abrieron un clima de más difícil consenso entre un Gobierno débil y una oposición fortalecida, los compromisos pactados fueron cayendo inexorablemente en la desatención y el olvido» ${ }^{148}$. No obstante, se llevan a cabo determinadas medidas liberalizadoras, principalmente en el ámbito industrial ${ }^{149}$. El régimen autorizatorio se sustituye en determinadas actividades por una comunicación de un proyecto técnico redactado por técnicos competentes, fijándose un período de tiempo para que la Administración señale o pida las declaraciones que considere oportunas. Transcurrido este plazo sin que el órgano competente no hubiera realizado ninguna manifestación, se entenderá que no hay inconvenientes por su parte para la ejecución del proyecto ${ }^{150}$.

El sistema administrativo cae durante estos años en una situación de descrédito, por lo que la reforma del mismo será el leitmotiv de los programas electorales de los partidos políticos ${ }^{151}$. Con la llegada al poder de los socialistas, tales refor-

147 Asf, puede citarse el olvidado Proyecto de Ley de reforma del procedimiento administrativo presentado en la I Legislatura por el Gobierno de la UCD (BOCG-CD serie A, de 26 de octubre de 1981. 226-1).

148 Vid. Joan Prats i CATAlA, «Administración pública y transición...», op. cit., pág. 454.

149 Para un análisis del nuevo régimen introducido por el RD 2135/1980, de 26 de septiembre, vid. Germán FERNANDEZ FARReres, «Industria» en Sebastián MARTIN-REToRTIUO BAQUER (ed.), Derecho administrativo económico II, Ed. La Ley, Madrid 1991, págs. 442-452.

150 Vid. en esta línea: RD 2135/1980, de 26 de septiembre, de liberalización en materia de instalación, ampliación y traslado de industrias en general (BOE 247, de 14 de octubre de 1980); RD 2738/1980, de 17 de octubre, de liberalización y de nueva regulación de las industrias agrarias (BOE 300 , de 15 de diciembre de 1980); Orden de 19 de diciembre de 1980 que desarrolla el RD de 26 de septiembre de 1980, sobre liberalización en materia de instalación, ampliación y traslado de industrias en general (BOE 308, de 24 de diciembre de 1980).

151 Son significativos determinados testimonios recogidos por Vicente María GonZÁLEZ-HABA GUISADo: «Sebastián Martín-Retortillo, a la sazón ministro adjunto para la Administración Pública, declaraba el 25 de noviembre de 1980 al diario Ya lo siguiente: "La Administración es lenta, ineficaz, irresponsable, inhumana, cínica, arrogante e indisciplinada"». Por su parte, el diario El Pais, en un editorial titulado 
mas parecen ser una prioridad, según se anuncia en el discurso de investidura del Presidente del Gobierno ${ }^{152}$. Lo cierto es que las mismas tardan en llegar centrándose, en la primera mitad de la década de los '80, en algunos aspectos organizativos y en temas de función pública (Ley 30/1984, de 2 de agosto).

Los problemas de carácter jurisdiccional siguen centrando una atención preferente en las reformas legislativas que vienen a adaptar la legislación vigente al nuevo contexto constitucional. Un momento importante lo constituye la aprobación de la Ley orgánica 6/1985, de 1 de julio, del Poder Judicial. En esta norma se contienen diversos preceptos que aluden al control jurisdiccional de la Administración pública. Son de gran interés, desde la perspectiva de este estudio, los precedentes parlamentarios. En éstos se encuentran algunas propuestas que hacen referencia expresa al tema de la inactividad administrativa.

Concretamente el art. 8 del Proyecto de Ley orgánica establecía que: «Los Tribunales controlan, sin excepciones, la potestad reglamentaria, así como la actuación administrativa, juzgando de su legalidad y sometimiento a los fines que la justifican». Pero es, sobre todo, el art. 36 del Proyecto donde se señala que: «En el orden administrativo será competente, en todo caso, la jurisdicción española cuando la pretensión que se deduzca se refiera a disposiciones de carácter general, actos u omisiones de las Administraciones Públicas españolas. [...]». Se venía a reproducir en este momento el intento que formulo el Grupo socialista en el debate constituyente, si bien de una forma más limitada pues no hacía ninguna referencia a la posibilidad de que los jueces sustituyeran la inactividad administrativa ${ }^{153}$. Cabe advertir que en este momento las circunstancias eran del todo distintas: este Grupo parlamentario disponía ahora de la mayoría absoluta que le permitía cómoda y holgadamente aprobar la Ley orgánica, im-

«El cambio que se espera. Que el Estado funcione» y publicado el 23 de noviembre de 1982, afirmaba lo siguiente: «El futuro Gobierno socialista heredará, así, una Administración elefantiásica, cara, ineficiente, torpemente intervencionista, mal preparada para dirigir una sociedad industrial en tiempos de crisis y atrincherada tras gruesos muros de piedra insolidaria que la aíslan de unos administrados a los que ignora. Y en su reciente libro ¿Por qué no? Una propuesta catalana para la modemización del Estado, RoCA JUNYENT critica duramente a la Administración del Estado a la que acusa de que «es farragosa, cara, reiterativa y poco imaginativa; su actuación o está dirigida a controlar y limitar la acción de los particulares, o bien a sustituirla, pero casi nunca a ayudar o a servirla». Vid. «Los partidos políticos ante los funcionarios» en $D A$ 198, abril-junio 1983, págs. 209-210.

152 Así, Felipe GonzÁlez afirma el 30 de noviembre de 1982 que «no es sólo la Justicia, sino toda la Administración la que requiere serias reformas» para librarla «de trabas heredadas, de procedimientos anticuados y de comuptelas poco tolerables, a fin de que se convierta en un eficaz ejemplo de servicion. Vid. Vicente-María GonZÁlez-HABA GuISADO, «Los partidos políticos...", op. cit.

153 Vid. Joaquim FERRET I JACAS, «El control jurisdiccional de la inactividad administrativa» en $D A$ 208, abril-diciembre 1986, pág. 270. Trabajo publicado originariamente en lengua catalana en AA.VV.: Estudios sobre el Proyecto de Ley Orgánica del Poder Judicial, Ed. Escola d'Administració Pública de Catalunya, Barcelona, 1985, pág. 85. 
LA EVOLUCIÓN HISTÓRICA DEL SILENCIO ADMINISTRATIVO: ..

poniendo el criterio que había mantenido anteriormente. Sin embargo, las propuestas formuladas a este respecto no llegan a buen puerto. Las razones de ello se encuentran en una no muy afortunada intervención del propio representante del Grupo parlamentario Socialista, el Sr. Navarrete Merino, a la cual se une posteriormente un descuido en la redacción del texto final. Paradojicamente tal intervención no se produce al hilo de una enmienda formulada al art. 36 del Proyecto, sino por una «corrección terminológica (sic)» que introduce el diputado socialista sustituyendo la expresión «omisiones» por la de «actos expresos o tácitos» ${ }^{154}$. Corrección que fue aprobada por unanimidad por la Comisión de Justicia e Interior. Ello pese a que la doctrina había advertido nítidamente, según veremos más adelante que los actos tácitos no constituían una forma de inactividad administrativa ${ }^{155}$. Lo más lamentable es que incluso desapareció, sin que se sepa realmente el porqué, la referencia a los «actos expresos o tácitos» quedando simplemente en el texto definitivo la expresión «actos» ${ }^{156} . \mathrm{La}$ explicación más plausible es que simplemente fue un descuido o error, no corregido ${ }^{157}$, en la publicación del texto. Quizás si se hubiera mantenido la expresión «actos expresos o tácitos» se hubiera podido realizar una interpretación flexible del precepto atendiendo a su sentido originario y prescindiendo de la falta de precisión terminológica.

El proceso descrito hasta ahora pone de relieve cómo el problema de la inactividad de la Administración pública era sentido esencialmente como una cuestión de control jurisdiccional. Esta reacción lógica trae causa en la necesidad de afirmar el Estado de Derecho, evitando que la Administración a través de actuaciones omisivas incumpliera la legalidad. Es posteriormente con el proceso de modernización y reforma procedimental que empieza en la segunda mitad de los años 80 , cuando se empieza considerar el problema de la inactividad no solamente desde la perspectiva judicial, sino como la necesidad de dotar de instrumentos a la Administración para agilizar su actividad, en sus relaciones con los ciudadanos.

154 Vid. el Diario de Sesiones del Congreso de los Diputados-Comisiones 272, de 4 de marzo de 1985, pág. 8.487.

155 Una crítica a la introducción de la expresión «acto tácito» en el Proyecto de Ley orgánica del Poder Judicial fue formulada por la profesora María Jesús MONTORO CHINER, «La inactividad administrativa en el proceso de ejecución de las leyes. Control jurisdiccional "versus" fracaso legislativo (Análisis en torno a las acciones de responsabilidad por daños derivados de la inactividad administrativa y legislativa por la "muerte de los bosques" en la RFA)» en RAP 110, mayo-agosto 1986, pág. 270.

156 Ello sucede a partir del texto aprobado definitivamente por el Pleno. Vid. el BOCG-CD, Serie A, 118-III, de 8 de abril de 1985.

157

Debe advertirse que a la publicación de la aprobación definitiva del Pleno le sucedio una corrección de errores en la cual también consta únicamente la expresión actos. Vid. el BOCG-CD. Serie A, 118-III-1, de 3 de mayo de 1985. 
La puesta en marcha de este proceso tiene lugar con un acontecimiento de extraordinaria trascendencia: la incorporación del Estado español al proceso de construcción de la Europa comunitaria a partir del 1 de enero de 1986. En relación al problema de la inactividad un primer síntoma de estos cambios lo constituye el Real Decreto-Ley 1/1986, de 14 de marzo, de medidas urgentes administrativas, financieras, fiscales y laborales, donde se prevé un régimen de silencio positivo para las licencias y autorizaciones de instalación, traslado o ampliación de empresas o centros de trabajo. Se aprueba, por tanto, un importante paquete de medidas de diversa índole donde destaca la incorporación del silencio positivo en unos determinados procedimientos administrativos y el propósito de evitar trámites burocráticos innecesarios con la finalidad que puedan surgir, con la mayor premura posible, empresas competitivas en el nuevo mercado.

La agilidad en la tramitación viene dada por la supresión para estas licencias de la denuncia de la mora, al mismo tiempo que la previsión del silencio positivo evitaría a los particulares tener que acudir a los tribunales para ver reconocido su derecho. Sin embargo, la aplicación práctica de esta normativa, conocida como Real Decreto-Ley Boyer, ha sido calificada como «rarísima» ${ }^{158}$. En efecto, la jurisprudencia restringe considerablemente su ámbito de aplicación ${ }^{159}$ excluyendo a las licencias municipales y autonómicas ${ }^{160}$, pese a la opinión sustentada por algunos autores ${ }^{161}$. Los tribunales prefirieron

158 Vid. Alejandro NiETo GaRCía, «El tiempo en el procedimiento (silencio, prescripción...)» en Ciudadanos y reforma administrativa. Jornadas celebradas los días 27 y 28 de junio de 1994, en la Sede de la Universidad en Getafe, Ed. Universidad Carlos III de Madrid, Cátedra Joaquín Ruiz-Giménez de estudios sobre el Defensor del Pueblo, Madrid, 1995, pág. 151.

159 De diez sentencias que hemos localizado sobre la aplicación del régimen sobre licencias previsto en el Real Decreto-Ley Boyer en ningún caso los tribunales entienden que se ha producido el silencio positivo. Vid. STS de 27 de junio de 1989 (ref. Ar. 5544) (licencia municipal para explotación de una cantera); STS de 14 de diciembre de 1990 (ref. Ar. 9970) (licencia para la instalación, apertura y funcionamiento del servicio de calefacción, agua caliente y tanque de 7.500 litros para almacenamiento de gas6́leo tipo «C»); STS de 25 de abril de 1991 (ref. Ar. 3083) (licencia para local destinado a saunabar); STS de 4 de marzo de 1992 (ref. Ar. 2130) (licencia municipal de apertura de establecimiento de cafe-bar); STS de 13 de abril de 1993 (ref. Ar. 2675) (licencia de actividad para Bar-Piscolabis); STS de 18 de mayo de 1993 (ref. Ar. 3783) (licencia de establecimiento destinado a actividad de mesón-restaurante); STS de 14 de julio de 1993 (ref. Ar. 5486) (licencia de establecimiento de 6ptica); STS de 2 de noviembre de 1993 (ref. Ar. 8772) (licencia de apertura de farmacias); STS de 26 de octubre de 1994 (ref. Ar. 7789) (licencia de apertura de farmacias); STS de 4 de abril de 1995 (ref. Ar. 2940) (licencia de apertura de galería comercial y licencia de obras).

160 Vid. la STS de 4 de marzo de 1992 (ref. Ar. 2130) (licencia municipal de apertura de establecimiento de café-bar).

161 Para Manuel Martinez Bargueño está «fuera de toda duda» la aplicabilidad del Decreto-Ley a las Administraciones locales y autonomicas, proclamando la superioridad del Decreto-Ley Boyer frente al Reglamento de actividades clasificadas. Vid. de este autor «Las medidas urgentes administrativas del Real Decreto-Ley 1/1986, de 14 de marzos en AA 42, semana 10-16 de noviembre 1986, pág. 2.365. 
LA EVOUCION HISTORICA DEL, SILENCIO ADMNISTRATIVO: ..

destacar la especialidad de los reglamentos dictados para el ámbito municipal (servicios y actividades molestas) frente al rango de ley de la nueva regulación. Además, el Real Decreto-Ley Boyer si bien teóricamente aumenta los casos de silencio positivo no introduce novedades significativas respecto a su régimen jurídico, advirtiendo que, para que corra efectivamente el silencio, es preciso que «los interesados presenten sus peticiones debidamente documentadas y éstas se ajusten al Ordenamiento Jurídico» (art. 1). Exigencia que continuó propiciando una interpretación restrictiva del silencio, fundamentada especialmente en la primacía del elemento legalidad, según hemos visto anteriormente.

Esta reforma procedimental del año 1986 era, como decía el propio Real Decreto-Ley Boyer, meramente experimental. El art. 105 de la CE contiene, además de una reserva de ley, un mandato al legislador para regular el procedimiento administrativo. Este mandato constitucional y la reciente incorporación a la Europa comunitaria constituyen unos referentes ineludibles en el proceso de modernización administrativa. En este sentido, el Ministerio Almunia impulsa en 1986 un estudio denominado Reflexiones para la modernización de la Administración del Estado (Ed. MAP, Madrid, 1986). Se abandona el concepto de «reforma», sustituyéndolo por el de «modernización» en un intento de ir más allá de las meras reformas normativas para asumir una nueva «cultura administrativa» ${ }^{162}$. Todo ello dentro de un proceso paulatino, anunciado por el PSOE en 1988 a través del denominado Programa 2000: «[...] el gobierno socialista [...] ha renunciado de antemano a una reforma total optando por un planteamiento de reformas escalonadas». Asimismo, la participación del Estado español en diversos foros internacionales va poniendo cada vez más de relieve la necesidad de modernizar la Administración pública y alcanzar un aceptable nivel de homologación europea ${ }^{163}$.

La integración en Europa no es sólo una operación política y económica, sino ante todo una operación administrativa, puesto que las grandes decisiones en aquellas materias se toman a través de mecanismos administrativos ${ }^{164}$. En este punto se debe destacar una Recomendación del Consejo de las Comunidades Europeas 90/246/CEE, de 28 de mayo de 1990, relativa a la aplicación de

162 Por su parte, una visión crítica sobre la modernización administrativa es planteada por el profesor Alejandro NiEto GARCLA: «Hace veinte años se hablaba de "economía, celeridad y eficacia", ahora de "modernización". Simples modas, porque parece muy dudoso que los reformistas de hoy pretendan algo distinto que los de ayer, aunque las consignas sean diferentes». Vid. «Reforma administrativa y modemización de la Administración pública: ¿Un problema pendiente?» en RVAP 23, 1989, pág. 125.

163 Es significativo en este sentido el documento de la OCDE La Administración al servicio del público, Ed. MAP, Madrid, 1991.

164 Vid. Alejandro NiETO GARCla, «Reforma administrativa y modernización de la Administración pública: ¿Un problema pendiente?» en RVAP 23, enero-abril 1989, pág. 131. 
una política de simplificación administrativa en los Estados miembros (DOCE 141, de 2 de junio de 1990). En este texto se recomienda prestar una atención particular a una serie de puntos, entre los que destaca a nuestro propósito: «d) sustitución de la necesidad de una resolución formal por procedimientos de aprobación basados en el silencio administrativo, con arreglo al cual se considera que la falta de respuesta de la Administración, transcurrido un determinado plazo, implica la aprobación de la solicitud».

Desde estas premisas se realizan una serie de estudios de evaluación organizativa realizada entre los funcionarios ${ }^{165}$ y una serie de acuerdos ${ }^{166}$, que culminan en el Plan de Modernización de la Administración del Estado aprobado en abril de 1992. Es en este contexto que surge la Ley 30/1992, de 26 de noviembre, de régimen jurídico de las Administraciones públicas y del procedimiento administrativo común (LRJPAC) ${ }^{167}$. Con esta Ley se introduce una nueva regulación del silencio administrativo, ampliando significativamente la extensión del silencio positivo al fijar unos supuestos de directa aplicación ${ }^{168}$, al mismo tiempo que reforzando la obligación de resolver respecto a la regulación anterior al extenderla a los procedimientos iniciados de oficio. La LRJPAC introduce como novedad la denominada certificación de acto presunto que no sólo sirve para acreditar la producción del silencio, sino que además constituye un requisito para su eficacia, por lo que se ha llegado a señalar que vendría a sustituir la denuncia de la mora prevista por la legislación sectorial.

\footnotetext{
165 Vid. Estudio Delphi sobre la modernización de la Administración pública, Ed. MAP, Madrid, 1990.

166 Así, el Acuerdo del Consejo de Ministros de 15 de noviembre de 1991, para el desarrollo de un Plan de Modernización de la Administración del Estado (publicado por el MAP, Madrid, 1991) y el Acuerdo Administración-Sindicatos para Modernizar la Administración y Mejorar las condiciones de Trabajo, aprobado por Resolución de la Dirección General de Trabajo de 3 de enero de 1992 (BOE de 21 de enero de 1992).
}

167 Sobre el contexto en que surge la LRJPAC es imprescindible el excelente análisis de Ángel SÁN. CHEZ BlanCo, «Los derechos ciudadanos en la Ley de Administraciones públicas» en RAP 132, septiembre-diciembre 1993, págs. 41 y ss.

168 Los supuestos de silencio positivo previstos en la LRJPAC pueden sistematizarse de la siguiente forma:

- Solicitudes de concesión de licencias y autorizaciones de instalación, traslado o ampliación de empresas o centros de trabajo (art. 43.2.a).

- Solicitudes cuya estimación habilitaría al solicitante para el ejercicio de derechos preexistentes, salvo que la estimación tuviera como consecuencia que se transfirieran al solicitante o a terceros facultades relativas al dominio público o al servicio público (art. 43.2.b).

- En todos los casos, las solicitudes en cuya normativa de aplicación no se establezca que quedarán desestimadas si no recae resolución expresa (art. 43.2.c).

- Resolución de recursos administrativos cuando éstos se hayan interpuesto contra la desestimación presunta de una resolución por el transcurso del plazo (art. 43.3.b).

- Suspensión en vía de recurso de la ejecución de un acto administrativo si transcurridos treinta días desde que se solicitó no ha recaído resolución expresa (art. 111.4). 
LA EVOLUCIÓN HISTÓRICA DEL SILENCIO ADMINISTRATIVO:..

Se establece además un nuevo supuesto de nulidad de pleno derecho en relación a los denominados actos presuntos para reforzar la posición del ciudadano afectado por la inactividad (art. 62.1.f). Parece que la nueva Ley quiere romper con la jurisprudencia que venía predicando la imposibilidad de adquirir por silencio facultades contrarias al ordenamiento jurídico. La LRJPAC establece finalmente una serie de reglas cuya concreción se realiza a través de un complejo proceso de adecuación de procedimientos ${ }^{169}$, previsto en la propia normativa e impulsado para la Administración del Estado a través de un Acuerdo del Consejo de Ministros de 15 de enero de 1993. Esta legislación ha sido objeto de una severa crítica por una gran parte de la doctrina, la cual no fue tenida en cuenta durante su elaboración. Así, las principales críticas han recaído por una parte en el grado de complejidad que introduce la nueva normativa, y por la otra en la gran fragmentación y dispersión producida por los reglamentos de adecuación a la LRJPAC. Debe señalarse, sin embargo, que al menos ha puesto a la luz más de dos mil procedimientos administrativos haciéndose una valoración sobre cuál ha de ser su plazo para resolver y los efectos de la falta de resolución. Toda esta legislación constituye, sin lugar a dudas, un importante material que debe tenerse en cuenta en los análisis doctrinales y que nos pueden servir para proponer soluciones más allá de la socorrida solución del silencio administrativo.

Cabe apuntar, además, que en enero de 1997 se realizaron en Sevilla unas jornadas sobre la reforma de la LRJPAC sobre unas Propuestas presentadas por los profesores Alfonso Pérez Moreno, Luciano PAREJoAlfonso y FrancisCO LOPEZ MENUDO, en base a las cuales realizar un reencuentro entre la doctrina y el legislador. Las citadas Propuestas sugirieron una reforma parcial de la LRJPAC para corregir ciertas disfuncionalidades, evitando perjuicios a la seguridad jurídica. Las novedades más significativas que se apuntan son retomar la clásica distinción entre silencio negativo y positivo (a los que se denomina respectivamente «desestimación presunta» y «estimación tácita» ${ }^{179}$, la sustitución de la certificación de acto presunto por una comunicación ${ }^{171}$, la eliminación del

169 Sobre la adecuación de procedimientos pueden destacarse los siguientes trabajos: Andres BETANCOR RODRÍGUEZ, «Régimen jurídico, organización y procedimiento administrativo» en Tomás FONT I Llovet (ed.), Anuario del Gobierno Local 1995, Ed. Diputació de Barcelona y Marcial Pons, Madrid, 1995, págs. 195-215; Pedro Manuel Herrera Molina; Fernando Serrano ANTÓN, «El reglamento de procedimientos tributarios ¿adaptación o huida de la Ley de procedimiento administrativo común? en Impuestos 19, 1993, págs. 70-83; Manuel IzQuIERDO CARRASCO, «La adecuación de procedimientos a la LRJPC. En especial, la determinación del sentido del silencio (Una regulación del procedimiento administrativo poco común)» en RAP 138, septiembre-diciembre 1995, págs. 387-404.

170 Sobre la expresión sacto tácito» recuérdese la crítica que se realizó a raíz del Proyecto de LOPJ. En cualquier caso, esta redacción tiene un excesivo contenido dogmático, más propio de la doctrina que del legislador.

171 Para unas valoraciones sobre este problema puede verse Vicenç AGUADO I CUDOLA, «La certificación de acto presunto» en Revista Juridica de Catalunya, 1997 (en prensa). 
supuesto de nulidad de pleno derecho del art. 62.1.f) de la LRJPAC, la previsión de unos plazos supletorios de resolución para los procedimientos iniciados de oficio y el establecimientos de unos supuestos de supensión de los plazos. A este proceso de reforma legislativa debe añadirse, asimismo, el relativo a la jurisdicción contencioso-administrativa iniciado en la etapa socialista ${ }^{172}$ y que vuelve a ser retomado en la correspondiente al gobierno del Partido popular ${ }^{173}$. El reto de construir una Administración pública adaptada a las nuevas exigencias de la sociedad continúa, por tanto, estando presente.

\section{RECAPITULACIÓN: LAS DIVERSAS CONCEPCIONES DEL SILENCIO ADMINISTRATIVO COMO RESULTADO DE LA EVOLUCIÓN HISTÓRICA DEL PROPIO ESTADO}

Según hemos podido constatar a lo largo de este trabajo, es fundamentalmente durante dos períodos autoritarios, los regímenes de los generales Primo de Rivera y Franco Bahamonde, cuando se perfilan los rasgos más característicos del silencio administrativo. Ambos períodos no suponen una ruptura del modelo de Estado y de Administración imperante en el Estado español durante largos períodos de tiempo, sino que llevan hasta sus últimas consecuencias los objetivos perseguidos por la oligarquía, sin los «estorbos» que propiciaba el régimen parlamentario liberal. La inexistencia y debilidad del parlamentarismo propicia la búsqueda de una legitimación del Poder en los órganos jurisdiccionales. Para ello hay que facilitar al máximo que los administrados puedan acceder a la jurisdicción y en este juego el silencio administrativo va adquiriendo sucesivamente un importante papel.

Durante estos períodos autoritarios se producen diversos intentos de establecer la técnica del silencio positivo. Estos intentos quedan, sin embargo, en su mayoría frustrados, bien porque se quedan en simples proyectos o bien porque cuando se convierten en normas positivas son objeto de un estrecho marcaje, como consecuencia de su interpretación jurisprudencial. A través de la misma se produce la absoluta inoperancia del silencio positivo, al mismo tiem-

172 Debe destacarse singularmente el Proyecto de Ley reguladora de la jurisdicción contencioso-administrativa del cual la versión última es la publicada en el BOCG $C D$, serie A, 3 de enero de 1996, 133-7. Este texto surgio de un Anteproyecto elaborado por una Comisión de expertos presidida por Jesús LEGUINA VI. LA, donde se prevén específicamente mecanismos de control de la inactividad administrativa. También tiene cierto interés, si bien menor desde la perspectiva de nuestro estudio, el Proyecto de Ley de organización y funcionamiento de la Administración General del Estado (BOCG-CD, serie A, 21 de octubre de 1995, 138-1) que alude en algún momento al tema de la simplificación de procedimientos.

173 Cabe decir que en la IV legislatura se ha vuelto a reemprender la reforma de la Ley de la jurisdicción contencioso-administrativa con la presentación por el Gobierno de un Proyecto de Ley en el Parlamento en junio de 1997. 
LA EVOLUCIÓN HISTÓRICA DEL SILENCIO ADMINISTRATIVO: ...

po que introduce graves dosis de inseguridad en la relación particular-Administración pública. Por otra parte, no se articulan mecanismos efectivos de dinamización de la Administración pública. De esta forma los grandes propósitos reformadores, sin duda de gran mérito, quedan desvirtuados por la práctica diaria. A ello se une ei hecho de que la legislación general, de gran calidad técnica, no se corresponde con las leyes sectoriales ni con la actuación de las Administraciones públicas.

La transición española viene a situar el elemento garantista en el cénit que se venía persiguiendo desde los años 50. Así, la CE incorpora en su articulado numerosas garantías y casi se viene a conseguir una consagración constitucional sobre el control de la inactividad administrativa. Con estos condicionamientos, el actual Estado social y democrático de Derecho se ve ante una mayor urgencia de adaptar el tempo de la Administración al nuevo contexto europeo, surgido con la incorporación del Estado español a la Unión Europea. Por ello se ha planteado concebir al silencio administrativo como un mecanismo de simplificación administrativa. Debe objetarse, sin embargo, a este planteamiento que difícilmente puede concebirse al silencio como un instrumento en manos de la Administración con el fin de agilizar los procedimientos. En efecto, pese a declaraciones triunfalistas, el silencio sigue siendo considerado por la normativa como una patología del resultado del incumplimiento de la obligación de resolver. Ante tal situación, deben buscarse dentro del procedimiento mecanismos alternativos que estén dirigidos directamente a dinamizar la actuación y no destinados a suplir las carencias ${ }^{174}$.

174 Sobre este punto vid. Vicenç AGUADO I CUDOLA, Silencio administrativo e inactividad (en prensa). 
